University of Louisville

ThinkIR: The University of Louisville's Institutional Repository

Electronic Theses and Dissertations

6-1927

\title{
Cooperation among American wage earners prior to 1890.
}

B. R. Justice

University of Louisville

Follow this and additional works at: https://ir.library.louisville.edu/etd

\section{Recommended Citation}

Justice, B. R., "Cooperation among American wage earners prior to 1890." (1927). Electronic Theses and Dissertations. Paper 718.

https://doi.org/10.18297/etd/718

This Master's Thesis is brought to you for free and open access by ThinkIR: The University of Louisville's Institutional Repository. It has been accepted for inclusion in Electronic Theses and Dissertations by an authorized administrator of ThinkIR: The University of Louisville's Institutional Repository. This title appears here courtesy of the author, who has retained all other copyrights. For more information, please contact thinkir@louisville.edu. 
A dissertation

Submitted to the faculty

of the Graduate school

of Arts and Sciences in

Partial fulfillment of the

Requirements for the Degree

of Master in Arts

DEPARTMINT OF SOCIOLOGY 
COOPERATION AMONG AMERICAN WAGT EARNERS PRIOR TO 1890

13201 
Dedicated to

John Greene Austin

whose interest has

followed me during

the years of prepar-

ation for a larger

Service. 
-. COMTEIITS --

CHAPTHR I. . . . . . . . . . . . . . . AIIS CHAPTER II...........ATTITUDE OF OFFICERS CHAPTHR III.................ATTIPTS CHAPTER IV...............USES OF FAILURE CHAPTHR $V \ldots \ldots \ldots \ldots \ldots \ldots \ldots \ldots \ldots$ BENETITS BIBIIOGRAPHY

$-0.000-\cdots$ 
C H A T ER I 
CHAPTER 1

\section{ATMS}

\section{Definitions}

Productive Cooperation - an arrangement by which the employes choose those who are to manage the business. Distributive Cooperation an arrangement by which the consumers manage the business and divide the profits. Profit Sharing - an arrangement by which the employes participate in the profits of the business.

\section{General}

"The aim,of cooperation is the substitution of common ownership and operation of trade and industry for individual or capitalistic ownership. The cooperator seeks common ownership not through the government, as does the socialist, but through voluntary association of producers or consumers." cooperators. Perhaps they were not as clear in their aim as they might have been, but in some way or other they sought for the day when labor should control industry. Whether they had in mind universal cooperation, or cooperation in the local sense, is not clear. Most likely they had in mind the bringing about of their desired aims by local cooperation.

T. V. Powderly, writing in 1887, giving what he termed the attitude of the Knights of Labor toward cooperation from their inception, said: "The fundamental principle on which the organization
(1) Eddy "The New Competition", Page 153
(2) Ford "Cooperation in New England", Page 4. 
(the K. of $I_{0}$ ) was based was cooperation, not a cooperation of men for the mere purpose of enhancing the value of their combined contributions to any productive enterprise alone, but a cooperation of the various callings and crafts by which men earned the right to remain upon the earth's surface as contributors to the public good. The barriers of trade were to be cast aside; the man who toiled, no matter at what, was to receive and enjoy the fruits of $h$ is labor and the exercise of $h$ is art, whether as a skilled artisan or as the humblest of the toilers of the earth."(1) This was written after attempts at local cooperation had proved a failure. We wonder if Powderly did not change his mind as attempts met with failure. At least the words of the Preamble to the constitution of the Knights of Labor were not changed from those of the fourth plank of the Preamble of the Industrial Brotherhood, and contained as their purpose "the establishment of cooperative institutions, productive and distributive:" (2)

As labor organizations grew in experience they began to see the difficulties of local cooperation, and that they must resort to something better. In assemblies and among leaders we begin, during the closing years of the period, to hear the cry for universal and not local cooperation. (3)

(1) Powderly, "Thirty Years of Labor", Page 151

(2) Preamble to Knights of Labor Constitution

(3) General Proceedings $K_{0}$ of $I_{0}$ 1882, Page 320. 


\section{Ownership of Railroads, Telegraphs, Telephones.}

The assembly of the Knights of Labor, meeting in Philadelphia 1884, added the following to the Preamble of the Order:

"That the government shall obtain possession, by purchase, under the right of eminent domain, of all telegraphs, telephones, and railroads; and that no charter or like-clause be issued to any corporation for construction or operation of any means of transporting intelligence, passengers, or freight." (1)

In the same meeting Powderly advocated the ownership of railroads, telegraphs and telephones, stating that he believed it was necessary for the public good. "So long as the entire control and management of the public highways of the country - the railroads - remain in the hands of private individuals while doing work of the Nation, just so long will the operation of cooperative enterprises be attended with failures." Aside from the fact that labor was concerned about governmental control as a stab at the monopolies, they were aware of the fact that the railroads conspired against them in their efforts to cooperate.

\section{Iand}

A great deal of attention was turned to the land question. Among the most prominent organizations who took part in the discussion against land monopolies was the Knights of Labor. The Grand Master workman, Powderly, was a bitter opponent of the ownership of

(1) General Assembly Proceedings K. of I. 1884, Page 769

(2) Proceedings 1884, Page 569

(3) General Assembly Proceedings K. of L. 1888, Page 8

(4) General Assembly Proceedings K. of I. 1884, Page 726 
(1)

land by.the few. He seldom made an address without calling attention to this impending danger. In $h$ is address before the General Assembly in 1882, he urged the question of governmental ownership of lands. He argued that no dying man had the right to say who should benefit from the land, and rose to oratorical heights when he spoke against the "Monoply of the Soil." The land, he contended, belongs to the people, and should be theirs to hold. It had been stolen from the people, he affirmed. Just how far the mass of wage-earners concurred in this sentiment we are unable to say. It is sufficient to say that this evil was a great hinderance to the ushering in of the reign of the common man, and remains to the present day.

\section{Strikes}

In conclusion, a word may be said about the attitude of labor toward strikes. From all accounts the efforts at cooperation were aimed at the elimination of strikes. Leaders were far sighted enough to see the fruitility of strikes. These were, they agreed, like beginning at the top of the tree. To get at the root of labor evils was to their mind cooperation and not strikes. In assemblies of the Knights, strikes were deplored and urged only as a last resort. The strike benefit fund was seen as dangerous, as it encouraged them. Men would strike for small reasons and remain out

(1) General Assembly Proceedings K. of I. 1882, Page 283 "Thirty Years of Labor", Page 336. Proceedings 1888, Page 9

(2) General Proceedings K. of I. 1882, Pages 312, 278, 311 General Proceedings K. of I. 1883, Page 414

(3) General Proceedings K. of $L_{0}$ 1880, Page 193; 1882, Page 318; 1883, Page 414; 1888, Page 8. 
as long as they were aided by the fund. Some urged that the strike fund be eliminated and the cooperative fund be strengthened. The labor papers began strongly to endorse cooperation as a cure for strikes.

(1) "National Labor Tribune" Nov. 29, 1886. 
C H P TER II 


\section{CHAPTER 1}

\section{ATMS}

\section{Definitions}

Productive Cooperation - an arrangement by which the employes choose those who are to manage the business. Distributive Cooperation an arrangement by which the consumers manage the business and divide the profits. Profit Sharing - an arrangement by which the employes participate in the profits of the business.

\section{(I)}

\section{Genera.}

"The aim of cooperation is the substitution of common ownership and operation of trade and industry for individual or capitalistic ownership. The cooperator seeks common ownership not through the government, as does the socialist, but through voluntary association of producers or consumers." "2his is a statement of the aim of early cooperators. Perhaps they were not as clear in their aim as they might have been, but in some way or other they sought for the day when labor should control industry. Whether they had in mind universal cooperation, or cooperation in the local sense, is not clear. Most likely they had in mind the bringing about of their desired aims by local cooperation.

T. V. Powderly, writing in 1887, giving what he termed the attitude of the Knights of Labor toward cooperation from their inception, said: "The fundamental principle on which the organization

(1) Eddy "The New Competition", Page 153

(2) Ford "Cooperation in New Fngland", Page 4. 
(the K. of $I_{0}$ ) was based was cooperation, not a cooperation of men for the mere purpose of enhancing the value of their combined contributions to any productive enterprise alone, but a cooperation of the various callings and crafts by which men earned the right to remain upon the earth's surface as contributors to the public good. The barriers of trade were to be cast aside; the man who toiled, no matter at what, was to receive and enjoy the fruits of $h$ is $l a b o r$ and the exercise of his art, whether as a skilled artisan or as the humblest of the toilers of the earth."(I) This was written after attempts at local cooperation had proved a failure. We wonder if Powderly did not change his mind as attempts met with failure. At least the words of the Preamble to the constitution of the Knights of Labor were not changed from those of the fourth plank of the Preamble of the Industrial Brotherhood, and contained as their purpose "the establishment of cooperative institutions, productive and distributive."

As labor organizations grew in experience they began to see the difficulties of local cooperation, and that they must resort to something better. In assemblies and among leaders we begin, during the closing years of the period, to hear the cry for universal and not local cooperation.

(1) Powderly, "Thirty Years of Labor", Page 151

(2) Preamble to Knights of Labor Constitution

(3) General Proceedings K. of I. 1882, Page 320. 


\section{Ownership of Railroads. Telegraphs. Telephones.}

The assembly of the Knights of Labor, meeting in Philadelphia 1884, added the following to the Preamble of the Order:

"That the government shall obtain possession, by purchase, under the right of eminent domain, of all telegraphs, telephones, and railroads; and that no charter or like-clause be issued to any corporation for construction or operation of any means of transporting intelligence, passengers, or freight."

In the same meeting Powderly advocated the ownership of railroads, telegraphs and telephones, stating that he believed it was necessary for the public good. "So long as the entire control and management of the public highways of the country - the railroads - remain in the hands of private individuals while doing work of the Nation, just so long will the operation of cooperative enterprises be attended with failures." Aside from the fact that labor was concerned about governmental control as a stab at the monopolies, they were aware of the fact that the railroads conspired against them in their efforts to cooperate.

\section{Iand}

A great deal of attention was turned to the land question. Among the most prominent organizations who took part in the discussion against land monopolies was the Knights of Labor. The Grand Master workman, Powderly, was a bitter opponent of the ownership of

(1) General Assembly Proceedings K. of I. 1884, Page 769

(2) Proceedings 1884, Page 569

(3) General Assembly Proceedings K. of I. 1888, Page 8

(4) General Assembly Proceedings K. of L. 1884, Page 726 
(1)

land by.the few. He seldom made an address without calling attention to this impending danger. In $h$ is address before the Genera.1 Assembly in 1882, he urged the question of governmental ownership of lands. He argued that no dying man had the right to say who should benefit from the land, and rose to oratorical heights when he spoke against the "Monoply of the Soil." The land, he contended, belongs to the people, and should be theirs to hold. It had been stolen from the people, he affirmed. Just how far the mass of wage-earners concurred in this sentiment we are unable to say. It is sufficient to say that this evil was a. great hinderance to the ushering in of the reign of the common man, and remains to the present day.

\section{Strikes}

In conclusion, a word may be said about the attitude of labor toward strikes. From all accounts the efforts at cooperation were aimed at the elimination of strikes; ${ }_{(3)}$ Leaders were far sighted enough to see the fruitility of strikes. These were, they agreed, like beginning at the top of the tree. To get at the root of labor evils was to their mind cooperation and not strikes. In assemblies of the Kuights, strikes were deplored and urged only as a last resort. The strike benefit fund was seen as dangerous, as it encouraged them. Men would strike for small reasons and remain out

(1) General Assembly Proceedings K. of I. 1882, Page 283 "Thirty Years of Labor", Page 336. Proceedings 1888, Page 9

(2) General Proceedings K. of I. 1882, Pages 312, 278, 311 General Proceedings K. of I. 1883, Page 414

(3) General Proceedings K. of $I_{\text {. }}$ 1880, Page 193; 1882, Page 318; 1883, Page 414; 1888, Page 8. 
as long as they were aided by the fund. Some urged that the strike fund be eliminated and the cooperative fund be strengthened. The labor papers began strongly to endorse cooperation as a cure for strikes.

(1) "National Labor Tribune" Nov. 29, 1886. 
C H P TER II 


\section{CHAPTER 11}

\section{ATTITUDE OF ORFICHRS}

The enthusiasm of early labor leaders was greater than that of early grange leaders because of a greater need. Their need was greater and their aim more radical. This does not imply, however, that the leaders were at any time very enthusiastic over (2) local cooperation. The Chicago Knights of Labor, a magazine of the order, said in 1886, "down with the strike assistance fund and up with the cooperation fund," and sought to raise $\$ 6,000,000.00$ in the. Order for the advancement of the "Cause."

There was an under current of opposition among certain labor leaders to what they called Competitive Cooperation. This was. especially true of the radical wing of the Socialist order. The (3) Denver Labor Tribune, the official organ of the "Red Internationals," declared against profit sharing. Another opposition was the International Working People's Association in Chicago relative to a proposed cooperative company formed by the packing-house strifes relative to a place to operate a large establishment of its own.

A meeting was called by radical Socialists which met at No. 71, West Iake St., Chicago, on November 28, 1886. The discuision taken from the Chicago Daily Tribune throws light on cooperative difficulties. The speech of $\mathbb{M r}$. T. J. Morgan, "the most outstanding

(1) Warner: "Three Phases of Cooperation in the West, "Page 50

(2) Ibid 101; Bemis: "History of Cooperation in U.S." Page 28

(3) Quoted from Warner "Three Phases of Cooperation in West" Page 50: 
opponent of 'individual corporation' is worthy of special (1) 'individual corporation' is worthy of specia note. He called for a special investigation into the conduct of those soliciting stock, and charged them with dishonesty. When he was criticised for this statement, he replied by saying that an investigation would aid and not hinder. He continued:

"The Socialists are charged with preaching cooperation to the working people, and now that they are about to put it in operation they say the Socialists are deriding it and putting obstacles in the way. I deny that Socialists have ever preached individual cooperation. We are in favor of universal cooperation, which means the destruction of the present competitive system. "To illustrate the development of the monopolistic system: When Chicago had 100,000 inhabitants and a few thousand more tributary to it, there were nine wholesale dry goods houses there. Then a man learning the business might one day have some hope of becoming a merchant himself. Now, with a population of nearly a million, and other millions tributary, instead of an increase over the nine, there is a reduction to four, and two of these could combine any day and crush out the other two - giving themselves a complete monoply of the business. What hope to a man learning the business now of ever himself becoming a merchant? So it is in other branches, both of distribution and production. The Standard Oil Company, the Antracite Coal pool, and the Gould and Vanderbilt systems of railways are striking and familiar examples of this development, while the Western Union Telegraph Company is an example of monopolistic development ready to become socialistic.

(1) Qupted from Warner "Three Phases of Cooperation in the West" Page 51 and 52. 
"The business of pork packing has developed far into the monopolistic state, and these are the reasons that this cooperative scheme will fail: Supposing the money to be subscribed, the buildings erected, the difficulties of securing managers of wide experience and honesty among members in the management overcome, and everything in readiness to buy hogs and turn them into pork, Armour will know about when his time will be, and shortly beforehand will, if he thinks his interest demands it, raise the price of hogs fourteen or fifteen cents above the normal price. The cooperative company must buy, because it cannot let its capital lie idle. The agents of the cooperative company buy, and the hogs are turned into pork. By that time Armour has depressed the price of pork fourteen or fifteen cents below the normal price. The company must sell in order to get money, but a short series of such experiences bankrupts the company. But there are other dangers. The operatives will own the stock and elect the directors, who appoint managers, foremen and superintendents, but the operatives are men who all their lives have been under bosses. The feeling that they are now bosses will cause insubordination - which foremen, superintendents and directors will fear to suppress, because they thereby endanger their positions. But suppose all these dangers safely passed, and the scheme a success, it only benefits those in the scheme; makes them contented and conservative, and loath to lend a sympathetic ear to the wrongs of workingmen not in the scheme, and does nothing to elevate the great mass of workingmen."

In this same debate Mr. August Kempfe was of the opinion that cooperation could not succeed until the educational benefits received through the eight hour system had been realized. Many 
speakers said that cooperative institutions had been aristocratic and monopolistic. Stockholders, they said, had become rich and "would not speak to workingmen." Mr. Schilling said that only a few picked men entered into cooperation and that this was a shame as it left those with less brain to work to their great dissatisfaction. One speaker said in this debate, sarcastically, that the pork packers were making money. One firm, he pointed out, had only lost $\$ 3000.00$ a week during a recent strike, as they had only killed five or six hundred hogs per day that they could not sell. Mr. Granville Sawyer was the only pronounced advocate of cooperation at the meeting. He said the cooperators did not attend the meeting. His contention was that cooperation was new and untried and should be given a greater chance ard that many were succeeding. He failed to see where Socialism was logical. They wanted state socialism but were opposed to operations on a sma.11 scale. Somebody must take the initative. If confidence among workingmen is so small, he continued, Socialism will never be. He was in favor of weeding out the shiftless and letting the picked men manage cooperation - rather an advanced idea for $h$ is day.

Mr. Morgan continued by ridiculing the idea of workingman's saving money. Manufacturers would say, "You can live on less than you do." He was opposed to distributive cooperation as the low cost of living would naturally reduce wages. He said that universal cooperation was said to be a long way off when, in fact, it was here already. He believed that soon the government would own the means of transportation, mail, water supply, fire systems, 
and that this would make every man, woman and child a shareholder. He concluded: "You say you can't wait for it, but I tell you, you have got to wait for it. Your duty until that teime comes is to get all the money you can for your labor, and, when you can save money from your small earnings, pay it into an agitation like this."

T. V. Powderly, Grand Master of the Knights of Labor, was apparently in favor of cooperation in the early days of his leadership; He said in 1880, in his opening address of the Assembly, "Cooperation.... system which will eventually make every man his own employer; which will give the laborer a fair proportion of the products of $h$ is toil. There is no good reason why labor cannot, through cooperation, own and operate mines, factories and railroads." People will then, he thought, regain their lost lands.

After seeing the failure of cooperative efforts during the next six years, he wrote, in his "Thirty Years of Labor," that universal cooperation was the only hope of the wage-earner. He recognized the greatest need to be that of education. "We have witnessed," he said, "the expenditure of millions of dollars for the support of strikes. We have seen the effect of boycotting; we have watched the course of our own cooperative enterprises and, as yet, cannot say with any degree of satisfaction that much of good has resulted." Out of the many hasty attempts, he claimed, only a very few had been successful. Fvery dollar invested in these hasty attempts was a dollar lost.

(1) General Proceedings of K. of I. 1880, Page 171

(2) Powderly, "Thirty Years of Labor", Page 469-470 
Francis Walker, an eminent economist, expressed grave doubt as to the success of cooperation, especially productive. (I) "The Union Printer," in an article afterwards printed in the $\mathrm{K}_{\mathrm{n}}$ ights of Labor (a most pronounced advocate of inmediate cooperation) treated the question as follows:

"The beaten path for writers on cooperation is to give the history of the Rochdale system pioneers; and follow it up with the history of cooperative stores of Great Britian, and then assert that there is no reason why our American wage-earners should not pursue the same course. But a single instance in which a writer here has studied out a plan for cooperation in his own trade, and submits it to his readers, is worth more in practice than this well worn chapter on cooperation in New England at the time when the cooperative stores obtained a hold there -. The fact is that in nearly every branch of trade the American consumer is next to the monopolistic manufacturer, the retail dealer being an agent rather than a dealer. The beer brewers of New York, for example, practically own most of the beer saloons in New York, and the retailer of beer is often more of a wage-earner for a brewer than an independent dealer. The score of New York dry goods stores whose advertisements fill up the pages of our $S_{\text {unday papers cheapen }}$ goods, as do the cooperative stores in England, by cutting off the profit of the small middleman. They are next to the manufacturers. A cooperative store on Twenty-Third Street was unable to compete with them. They centralize on immense volume of business, and then rent and payroll are very low in proportion -.. Now, let it be understood, that we are not writing down cooperation. Well-defined

(1) Quoted from Warner, "Three Phases of Cooperation in the West" Page 52-56. 
plans are wanted, and not forecast of the millenium. Our comments are directed chiefly toward the labor press-writers on the subject. Let them be cautious in giving an impetus to the labor movement in the wrong direction."

The above comment was a good warning, but the fact remains that there were a great number of organized laborers and officers who believed in cooperation. The meeting of the General Assembly of Knights of Labor in 1886 made one of its largest appoopriations to the cause of cooperation. "The future bids fair for cooperation, "thought Bemis, writing in 1887. The knights of Labor claimed that their ultimate purpose was to introduce a "Cooperative Industrial System," which some expected to become universal. "Leaders were too shrewd, however, to expect large results in the immediate future. It was difficult for the leaders to get the men to practical terms and to get them to begin in the realm of practical possibility. The leaders had learned in the school of adversity that too hasty attempts were to prove fruitless.

(1)

In 1886 , a Cooperative Board was appointed which was composed of twelve members, in the Knights of Labor. All these men had been in the midst of practical cooperation and were able to spend wisely. Mr. J. P. MoGaughey, Sedretary of the Board, published a letter stating that he desired copies of the constitution of all cooperative attempts; that he was in favor of practical attempts and for these to be taken care of locally

(1) K. of I. General Proceedings, 1886

(2) Ibid 1882, Page 320-21

(3) Warner: "Three Phases of Cooperation in the West," Page 58 
without aid from the General Assembly. Mr. John Samuels, a member of the Cooperative Board, wrote a pamphlet on "How to Organize Cooperative Societies," and gave five reasons for being a cooperator, with a statement of how the subject was regarded by the majority of workingmen, he said:

"Cooperation is the only way that I see by which the workers in this land or any other can raise their position to what it ought to be or might be. Hundreds and thousarids of persons have "got on", as it's called, by getting on the back of the workers. They have rolled up capital out of profit on their work and their trade. Now, cannot the workers get themselves, as a body, "on" to a higher standing ground? Cannot they roll up capital out of their own purchases and their own work to lift themselves up, one and all? I believe then can. But how? By union among themselves for this great end - the greatest end, I think, that men have ever knowingly worked for. Now, where does the road to this end begin? Where else, but in the store - which can give them capital out of their own income; which gives them business habits; which enables them to combine their powers by great commercial institutions, such as the cooperative wholesale societies; and action centers for propaganda, conferences, congresses, central and sectional boards, at once creating strength and showing them how to use it to best advantage and for the noblest purposes." 
C H A P T E R 11.1 
(I)

Statistical Tables

DISTRIBUTIVE COOPERATION

\begin{tabular}{|c|c|c|c|c|c|c|c|c|c|c|}
\hline & Incetion & Dat & & Capita & $:$ & $\begin{array}{l}\text { No. of } \\
\text { Shares }\end{array}$ & & g. & : Annual & $\begin{array}{l}\text { Method of Divid. } \\
\text { : ing Profits }\end{array}$ \\
\hline W Bedf & :New Bedford & & $:$ & & $:$ & & $:$ & & $:$ & :Equal \% Dividends \\
\hline Con & :Nass. & $: 1876$ & $: \$$ & 3000 & : & 300 & $:$ & 94 & : $\$ 48000$ & son Purchase of all \\
\hline n. & $:$ & : & $:$ & & & & $:$ & & $:$ & $:$ \\
\hline perati & :Silver Lake & & : & & & & & & & \\
\hline$f$ & $\begin{array}{l}\text { :Kingston, } \\
\text { :Mass. }\end{array}$ & $: 1875$ & $: \$$ & 1800 & 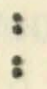 & 360 & : & 40 & $\$ 10,500$ & " \\
\hline & : & $:$ & $:$ & & & & : & & $:$ & 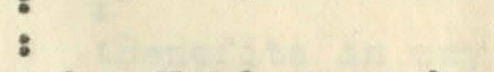 \\
\hline ams Coo & & $:$ & $:$ & & & & 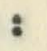 & & & : One Half as much \\
\hline ociat & : Adams,Mass & :1886 & $\mathbf{t} ;$ & 15000 & & 300 & : & 175 & - & - Dividend on trade \\
\hline & $:$ & : & $:$ & & & & & & $:$ & : to non-members as \\
\hline & : & : & & & & & & & & : to members \\
\hline insto & : Lawrence, & $:$ & : & & & & 8 & & 8 & $: \quad$ : \\
\hline P. A & Mass. & $: 7884$ & $: \$$ & 5755 & : & 451 & 8 & 351 & $: \$ 50,000$ & :10\% on Purchase " \\
\hline $\begin{array}{l}\text { Brita } \\
\text { p. Sto }\end{array}$ & $\begin{array}{l}\text { New Bri } \\
\text { Conn. }\end{array}$ & 1876 & $: \$$ & 12700 & $:$ & 200 & & 200 & $: \$ 75,000$ & - for Uembers $5 \%$ on \\
\hline & $: \quad 0$ & & 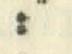 & & : & & & & & Purchase for Non- \\
\hline & 8 & $:$ & $:$ & & : & & & & 8 & :Members \\
\hline $\begin{array}{l}\text { Danvers Coop. } \\
\text { Union Society }\end{array}$ & $\begin{array}{l}\text { Danvers, } \\
\text { Mass. }\end{array}$ & $: 1865$ & $: \$$ & 5000 & & 1500 & & 499 & $: \$ 25,000$ & " \\
\hline ion soc. & : Mass. & $:$ & $:$ & & : & & & & 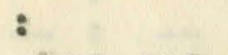 & \\
\hline $\begin{array}{l}\text { verside Coop. } \\
\text { Maynard }\end{array}$ & $\begin{array}{l}\text { Maynard, } \\
\text { Mliss. }\end{array}$ & $: 1875$ & $: \$$ & 5000 & $:$ & 1000 & & 260 & $: \$ 36,000$ & : \\
\hline & & & : & & : & & & & & :Dividend on Pur- \\
\hline $\begin{array}{l}\text { Lowell coop. } \\
\text { Assn. }\end{array}$ & $\begin{array}{l}\text { Lowell, } \\
\text { "Mass. } \\
\text { : }\end{array}$ & 1876 & $: \$$ & 10000 & & 2000 & & 500 & $\$ 50,000$ & : chase of Irembers \\
\hline son $F$ & on Falls & & $:$ & & $:$ & & $:$ & & & $:$ \\
\hline Coop. Ass: & Mass. & 1885 & : & & $:$ & & & & $: \$ 2$ & \\
\hline & $\begin{array}{l}\mathrm{Bi} \\
\mathrm{Co}\end{array}$ & & $: \$$ & & : & 84 & & 84 & $:$ & $\begin{array}{l}10 \% \text { on Purchase } \\
\text { to Members }\end{array}$ \\
\hline
\end{tabular}




\begin{tabular}{|c|c|c|c|c|c|c|c|c|c|c|}
\hline IName & :Iocation & Date & $: c$ & CapitaI & & o. of & & lold & $\begin{array}{l}\text { : Annual } \\
\text { : Trade }\end{array}$ & $\begin{array}{l}\text { : Method of Divid- } \\
\text { : Ing Profits }\end{array}$ \\
\hline Division 108 & :Selmon Frils & 8 & 8 & & $:$ & & 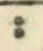 & & 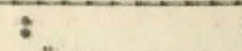 & $\$ 6 \%$ Int. to Capital \\
\hline$:$ & :Ilas & $: 1850$ & $: \$$ & 6986 & 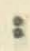 & 341 & $:$ & 202 & $: \$ 48,000$ & LLow Price to \\
\hline : & $:$ & : $:$ & $:$ & & & & : & & $:$ & EIvery One. \\
\hline Protect- & ck, & & $:$ & & & & $:$ & & & $: \quad-1-1-1+1$ \\
\hline :Ive & slis: & 866 & $: \$$ & 6000 & & 595 & : & 600 & $: \$ 100,000$ & ): \\
\hline : & : & $:$ & : & & & & : & & $:$ & $:$ \\
\hline - Store of & ster, & : & $:$ & & & & : & & $:$ & : \\
\hline est & & 76 & $: \$$ & 0 & & 32 & & - & $: \$ 40$ & : \\
\hline$:$ & $:$ & & : & & & & : & & : & $:$ \\
\hline ercan- & :Worcester, & $:$ & : & & & & : & & & :Benefits in way of \\
\hline :tile Assn. & :11ia & :1884 & $: \$$ & 2300 & & 460 & 5 & 96 & :\$19 & : dividends on stock: \\
\hline ; & : & : & : & & & & 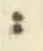 & & : & :and low prices \\
\hline : & : & : & $:$ & & & & & & \& & sonfined to member \\
\hline :01d Spain Coop. & : Weymouth, & & $:$ & & & & $:$ & & : & 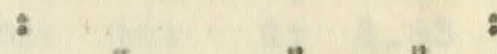 \\
\hline iety & :Ila & :1882 & $: \$$ & 1500 & & 300 & : & 130 & $: \$ 30,000$ & : \\
\hline Acushnet Coop. & :New Bedford, & & : & & & & $:$ & & 8 & $:$ \\
\hline Society & :Mas & :1859 & $: \$$ & 6875 & 8 & 275 & : & 107 & $: \$ 65,000$ & it \\
\hline Denvers Coop. & :Danvers, & & 8 & & & & $:$ & & $\sin ^{-10}$ & $:$ \\
\hline Society & :IIra & 371 & $: \$$ & 2500 & & 50 & $\therefore$ & 50 & $: \$ 36,000$ & $:$ \\
\hline Brockton Coop. & & & : & & & & $:$ & & $:$ & : \\
\hline Store & :Brockton, Mas & $: 1886$ & $: \$$ & 3000 & 8 & 600 & $\because$ & -- & -- & $:$ \\
\hline Coop. Market of & : Webster & : & $:$ & & & & 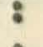 & & $:$ & \\
\hline Webster & $:$ & :1886 & $: \$$ & 1000 & & 200 & $:$ & -- & -- & : \\
\hline K. of I. Coop. & :N. Brookfield & & $:$ & & & & $:$ & & $:$ & $:$ \\
\hline Store Assn. & :llass. & : 1886 & $\therefore$ & 100 & \& & 200 & $:$ & $-\infty$ & -- & $:$ \\
\hline Coop. & Olneysville, & $:$ & 8 & & : & & $:$ & & $:$ & $:$ \\
\hline & :R.I. & $:$ & 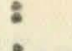 & & & & 8 & & $:$ & 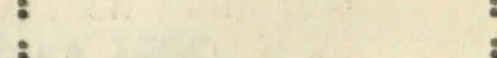 \\
\hline Coop. & :Lowell, lrass. & & $:$ & & & & $:$ & & 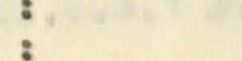 & $:$ \\
\hline dienne de & : vase & $:$ & $\therefore$ & 5000 & & & $\vdots$ & & 8 & : \\
\hline $\begin{array}{l}\text { Lowell } \\
\text { Central Union }\end{array}$ & :Nass & $:$ & $:$ & & 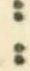 & & $:$ & & $:$ & $:$ \\
\hline A.SS & : & : & & & $:$ & & $:$ & & : & \\
\hline
\end{tabular}

IIr. Fdward Bemis, writing in 1887, thought it was safe to estimate the entire business of distributive cooperation in New England at $\$ 2,000,000.00$. This, however, includes cooperatia $\bullet$ among farmers.

(1) Bemis, "History of Cooperation in U.S." Page 129. 
The following table was taken from reportsgiven in the Massachusetts Iabor Bureau Report of 1886, giving the figures of 1885 :

1. Name

2. Location

3. Date of Organization
4. Annual Product

5. Capital

6. Number of Shares
7. Mo. of Shareholders

8. Stockholders Bmployed

9. Non-Stockholders Employed. 10. Average Dividends

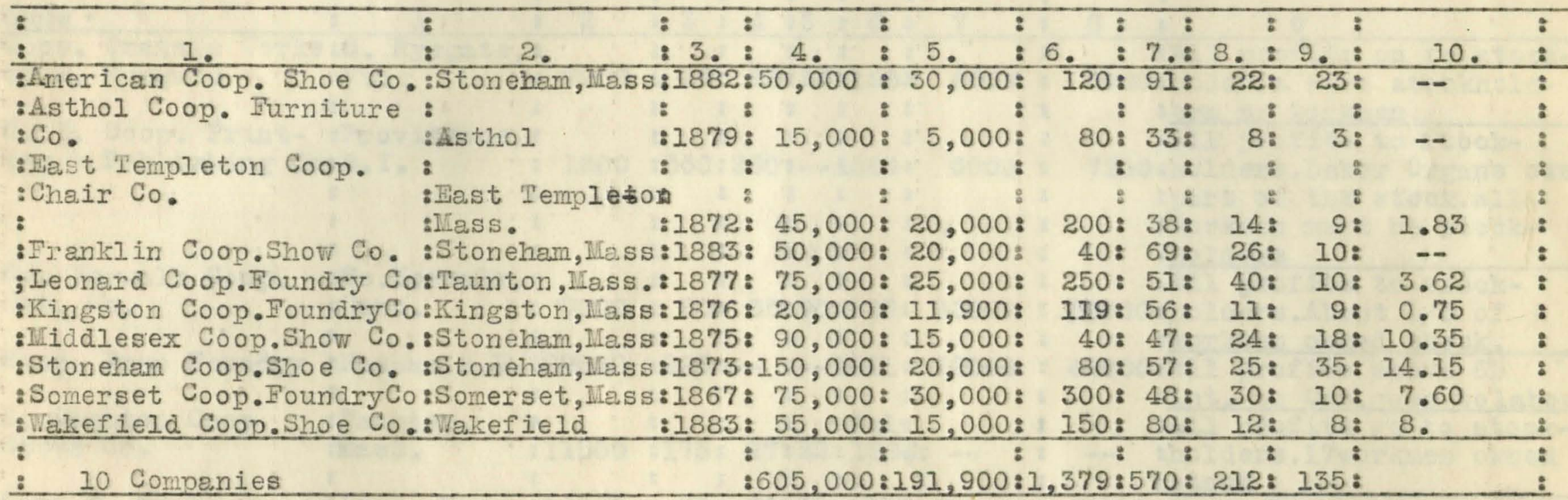

The above ten companies in all probability did a business in 1886 of approximately $\$ 665,000$ according to Mr. Bemis! $(2)$

(1) Condensed from Bemis, "History of Cooperation in U.S." Page $130 f$.

(2) Ibid 130 
The statistics of the following ten companies were gathered by returns from cooperative companies other than in the preceding table. All these were in business in 1886.

1. Iocation 4. No. of Shareholders

2. Capital

5. Mo. of Workmen

3. No. of Shares
6. Date of Beginning Business

7. Business in 1886

8. Estimate of Business of 1887, based on business of Mov, to Jan. 1886-7.

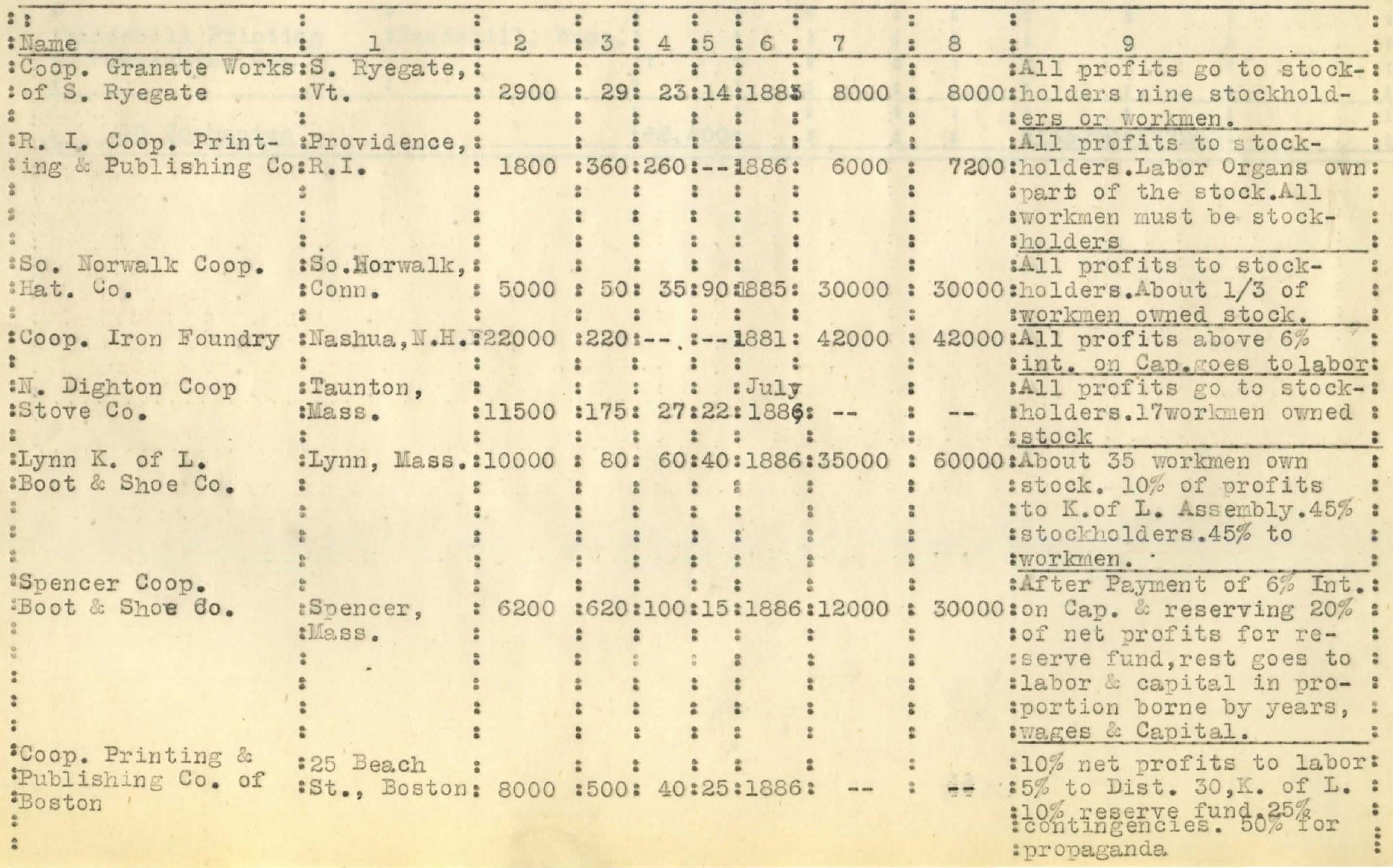




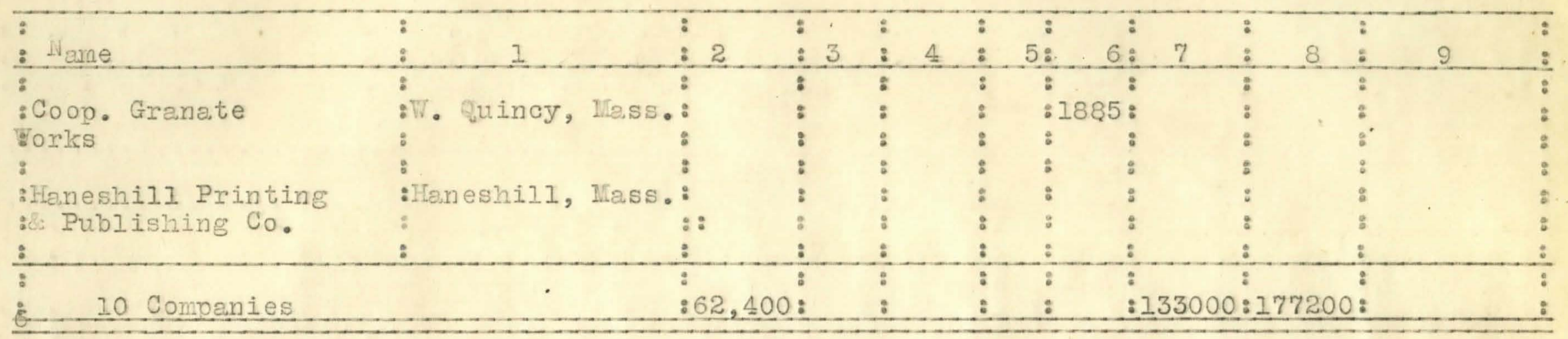




\section{(1)}

DISTRIBUTIVE COOPERATION

Only a few of the cooperative attempts given in the table of Distributive Cooperation in New Fngland will be treated. The Sovereigns of Industry were active during their existence with successful results at cooperation. Before 1890, famers, strange to say, were more cooperative or rather more successful in attempts at cooperation than were wage-earners. This was true not only of the New England States but of the West and other sections. However, IIr. Warner made the statement in 1887 that cooperation among farmers was a thing of the past in the West, and that cooperation among wage-earners there was a thing of the future.

\section{DISTRIBUTIVE COOPERATIVE ATITIIPTS}

1. DAIVERS COOPERATTVE UITION SOCTETY:

\section{(3)}

One of the oldest and most succesful cooperative companies in Jew Ingland was the Cooperative Union Society of Danvers, Mass. This company began in 1865 on the principle of the old union stores sales at cost to stockholders. No sales were rade to outsiders until 1869. It was incorporated under the laws of llassachusetts and much the same features as governed the Rochdale system were adopted.

The cepital, as incorporated, was $\$ 5000$ of $\$ 10.00$ shares. To one was allowed to hold more than twenty shares and six percent was paid on stock held. Proper deductions were made for depreciations,

(1) Z. W. Bemis, "Cooperation in New England"

(2) Warner, "Three Phases of Cooperation in the West," Preface (3) Bernis, Pages 53-54. 
and, after ten percent was taken for the surplus fund, the remainder went to the stockholders in proportion to trade. For the last six years, ending 1887 , dividends averaged. twelve percent. The trade of 98 stockholders was about three-fourths of the whole. The building was owned by the association, and business in 1886 was $\$ 25,000$. Five directors audited the accounts, which were open to all for examination.

\section{THE ARLIIGGON COOPTERATIVE ASSOCIATION:}

This association began business October 27, 1884. The Clerk, Mr. Geo. Dewhirst, wrote, "We find no difficulties in management, management, many of us beirg familiar with the Rochdale plan. We do not rely solely on a professional manager." The association did not confine its membership, after 1886, to employes in the Arlington Ilills, but accepted application from the general public. These applications were passed on by the Exxecutive Committee. Shares were $\$ 5.00$ each. After paying $5 \%$ interest on capital and $10 \%$ net profits to the reserve fund, the balance was divided on trade, one half as much going to non-nernbers as members. The number of members grew from July lst to October I, 1886, from 308 to 351 , and paid-up capital from $\$ 4,360$ to $\$ 5,755$. During this quarter the gross sales were:

$\begin{array}{lr}\text { On Merchandise } & \$ 9,637.97 \\ \text { On Dry Goods } & 233.77 \\ \text { On Boots d Shoe Accounts } \begin{array}{r}640.42 \\ \text { Thel }\end{array} & \begin{array}{r}2,226.02 \\ \$ 12,738.18\end{array}\end{array}$

A dividend of eight percent to members and four percent to nonnembers was given. The sales for the second quarter 1887 were $\$ 16,838.53$; the paid-up capital had grown to $\$ 8,715$, and the 
membership to 505. Mr. Dewhirst wrote that the report in October, 188\%, "Will show one of the best results ever attained by a young association in this country."

\section{(I)}

3. ACUSHIET COOPERATIVE ASSOCIATION:

Beginning in September, 1859, this company, located at Bedford, Mass., is the third in age of any of the cooperative enterprises of New England. It gradually grew in strength until 1887; it had a capital of $\$ 6,875$ in $\$ 25.00$ shares, awned by 107 stockholders. There was also a surplus of $\$ 5,288$. During the seven years beginning with 1880 the company declared dividends averaging 27\%. From 1869 to 1886 the dividends amounted to $\$ 38,088.00$. There was no dividend on purchase. The company had an annual trade of from $\$ 60,000$ to $\$ 70,000$. Only $\$ 3000$ had been spent for labor and the credit had been guarded so closely that only $\$ 400$ was lost in that way in the twenty-seven years prior to 1886 .

\section{(2)}

4. ADAIIS COOPERATIVE ASSOCIATION:

One of the most promising stores on "Approved Principles" was the Adams Cooperative Association, at Adams, Hass. Though only opened in September, 1886, the company had 300 five dollar shares in the hands of 175 members, and a trade of $\$ 1,200$ per month. At the close of the first quarter 18 $\frac{1}{2} \%$ was declared on capital. After paying six percent interest on capital, the remainder was paid to purchasers - non-members receiving one half as much as members.

(1) Bemis, "History of Cooperation in the U.S." Page 66 (2) Ibid, Page 70 
A few of the attempts at productive and distributive cooperation among wage-earners in New England are given to show the degree of success attained by the end of the period - 1887. We see that these efforts are mainly attempts with little success. We are unable to find how long these companies, undertaken with high hopes, lasted. The "Causes of Failure" in another part of this paper will suggest that a long period of education and experience must. pass before many such undertaking's could be called successes.

\section{SOMDURSET COOPHRATIVE FOUNDRY:}

The oldest organization of Productive Cooperation which survived to the end of the period was the Somerset Cooperative Foundry, organized at Somerset, Mass., October 18, 1867. "It may be called a joint-stock cooperative company, if such a name is admissible, since it combines the cooperative principles of large ownerships of stock by workmen in small shares, and with equal vote in the management, with the joint principle of dividing profits wholly on stock," (Bemis, "Cooperation in New Ingland). The company, with $\$ 30,000$ in $\$ 100$ shares owned by forty-eight stockholders, in 1887, had been turning out an annual product of $\$ 75,000$ and paying dividends of 10\%, since 1880 . Thirty of the forty-eight stockholders worked in the foundry. The management could discharge any man, if a poor worlman, but were not compelled to do so. Mir. F. H. Giddings, in the Massachusetts Labor Report
(1) Bemis, Page 78 
of 1886 said, "Members individually and the management, as such, declare that they are satisfied that stock owning improves the quality and increases the quantity of work accomplished, and that this goes to account for the success attained."

2. FAST THEPLIFTON COOPERATIVE CHAIR CONPANY:

This, the second oldest cooperative manufacturing in the State of Mass., was organized October 19, 1872. The capital in 1886 was $\$ 20,000$ in $\$ 100$ shares. Fourteen stockholders were employed by the company. The value of the product was about $\$ 50,000$. Few losses were incurred and dividends of 4 and 6 percent were declared in the most prosperous years. Few changes of management occurred during its long history.

\section{THE STONEHORIN COOPERATIVE SHOE COMPAIVY:}

This company was organized in a town where three other Cooperative Shoe Companies were located. It was organized on January 9, 1873. In 1886 it had a capital of $\$ 20,000$ in eighty shares, in the hands of fifty-seven stockholders. Nearly forty hands were employed, besides twenty-five stockholders. The annal product was $\$ 150,000$ and, from 1878 to 1887 dividends to the amounts of $17,15,15,21,20$ and 6 percent were declared. It was hampered by insufficient capital, as were many other enterprises.

4. THE MIDDIESEX COOPERATIVE BOOT AND SHOE COMPANY:

Though this company met with many losses soon after its start in 1875, owing to the failure of certain debtors, it had in
(1) Ibid, Page 79
(2) Bernis, Page 79
(3) Tbid, Page 79
(4) Ibid, Page 80 
1886, a capital of $\$ 15,000$ in 60 shares. The record of dividends is as follows:

$\begin{array}{ll}1876,9 \% & 1881,10 \% \\ 1887,10 \text { s } & 1882,20 \% \\ 1878,5 \% & 1883,25 \% \\ 1879,4 \frac{1}{2} \% & 1884,20 \% \\ 1880,10 \% & \end{array}$

Twenty-five stockholders and eighteen non-stockholders were employed in 1886. The treasurer said, "Cooperation must be of good habits, economical and saving. They must belong to the place and have a permanent interest in it."

5. COOPERATIVE GRAITATE WORKS OF SOUTH RYEGATE, VERIIONT:

In 1886, these had a capital of $\$ 2,900$ in $\$ 100$ shares, owned by twenty-three stockholders. There was no limit to the amount of shares one could hold. The business began in May 1885, as a result of stonecutters being thrown out of a job. The yearly business was reported to be from $\$ 8000$ to $\$ 10,000$ with business growing. The Secretary, J. D. Grant, wrote in 1886 that they were lacking in capital but added that "We believe cooperation is the missing link between labor and capital, and no matter how many experiments may fail, the ultimate result will be success."

6. SOUTH INORWALK COOPERATIVE HAT COMPAIIY:

This company was organized in 1885 , as a result of a lockout. By conditions in the constitution, capital was not to exceed $\$ 9000$ in $\$ 100$ shares. Half of this had been raised in 1886. No one was allowed more than three shares. The shareholders numbered thirty-five. From ninety to one hundred workmen were

(1) Bemis, Page 81 
employed in the busy season. Business was groving in 1886 and they were making two hundred hats of the derby style weekly. The bookkeeper remarked to $\mathrm{Mr}$. Bemis that "every book is open to every shareholder. Some feel themselves a little above everybody else, but no great trouble has been experienced."

7. LYMI KIVIGHTS OF LABOR COOPERATIVE BOOT AIN SHOE COIPAIV: During the year 1885 and following, the Knights of Labor were planning a great forward movement in productive cooperation in Massachusetts. The Boot \& Shoe Company at Lynn was one of these cooperative projects. Under the leadership of Mrr. Richard Magle, who was formerly Master Workman of District 77 of the Knights of Labor, this company started in April, 1886. Although great difficulties were encountered because shares at $\$ 100$ seemed hard to secure, $\$ 5000$ was secured. To their utter surprise it was found that at the end of ten weeks they had made $\$ 10,000$ worth of goods and were $\$ 200$ ahead. The capital in January, 1887, was $\$ 9000$ in the hands of about sixty persons. Ten shares was the limit anyone could hold.

1. There was a store previously at Peabody, near Iynn, which bought shoes from the Lynn Cooperative store. This store sold stock at five dollars a share. A member was selected to exchange stock in this company for stock in the Lynn store, so that it might become a branch store of the Lynn Company. The stock was raised to 2,500 and the profits were divided as follows: Ten percent for the sinking fund; five percent interest paid on
(1) Ibid, Page 86
(2) Bemis, Page 87 
the capital stock; ten percent to the Knights of Labor cooperative fund to assist other undertakings; forty five percent to capital and forty five percent to labor in proportion to wages. All workmen were required to be members of the $\mathrm{K}$. of $\mathrm{L}$. Over forty were employed in 1887, nearly all being stockholders. Business at the beginning of the year 1887 was good, and in the year previous the business averaged $\$ 5.00$ per month. Lany were opposed to the store, especially other dealers. One dealer refused to sell to the Peabody Firm even for cash. This, however, did not daunt the courage of the undertaking.

2. SPIITCER COOPERATIVE BOOT AND SHOE COMPAINY

(1)

At Spencer, Mass., a similar company began operation. It was incorporated under the laws of llassachusetts, April 12, 1886, with a capital stock of $\$ 6,000$ in the hands of about one hundred shareholders. Because of poor management, the company did a viery poor business the first few months of its existence. Because of the fine quality of shoes produced and because of proper management, the company began soon to turn out a monthly product of $\$ 2,500$. Only $K_{\text {. of }} \mathrm{L}$. members were employed. Goods werv bought and sold for cash or a very short credit. After paying $6 \%$ interest on capital and after deducting twenty percent for a sinking fund, the body of employes received such a part of the net profits as their combined yearly wages bore to the capital.

(1) Ibid, Page 88 
3. THE COOPERATIVE PRINTING \& PUBLISHING COIPAIY OF BOSTON: This company was begun on very much the same order as the Cooperative Boot and Shoe Company of Lynn. But because of poor patronage by the labor organizations, whose trade they hoped to get, and from bad management, the company failed in a very few months.

4. THE COOPERATIVE IRON FOUIDRY COIPANY OT INASHUA, N. This company, founded in 1881, began with a capital of $\$ 4,000$ which was increased to $\$ 8,000$, and finally to $\$ 22,000$, . was doing a business in 1887 of $\$ 40,000$ annually. Stock a.lways sold at a premium as high as 115 dollars on the 100 dollars. The future plans, after 1886, were to divide the profits among the workingmen, stockholders, and non-stockholders.

5. THE ITATIONAI KNIGHTS OF IAAOR COOPERATIVE ELASTIC TABRIC COMPANY OF CHELSEA, MASS.(2)

For the purpose of manufacturing suspender web, Goring web, elastic web for gloves, etc., this company purchased and paid for twenty thousand feet of land at fifteen cents a foot, erected and paid for a building one hundred by forty six feet and put in a part of the machinery, so that it expected to go to work early in 1887 . The capital stock was $\$ 5,000$ at $\$ 5.00$ a share, no one being allowed more than one hundred shares. Only Inights of Labor were allowed to hold stock or to work in the factory. After enumerating some of the difficulties already encountered, Mr. Leonard M. Small wrote: "But we will get there

(1) Bemis, Page 90
(2) Ibid, Page 91 
before long, and have already a number of customers ready to take our goods."

Cooperation, both distributive and productive, was in New Ingland, as other sections barely getting a start before 1890. Just how far these cooperative attempts were to prove successful, we have been unable to ascertain. The vast majority have died for reasons given in our discussion of the causes for failure. 


\section{ATTMPTS - IITEGRAI}

WAGE-TARNEPRS IN THE VEST

(1)

Before 1890 wage-earners in the West were not, in any great measure, successful in efforts of cooperation. The history of attempts necessarily results in accounts of (2)

attempts and failures. Warner said that any treatment of cooperation, especially in the West, was among farmers, for the most part, a thing of the past; while cooperation among wage-carners, so far as practical operations were concerned, mainly of the future. At Cincinnati, Chicago and St. Louis, great industries were coming into existence, but since the country was practically new, and land plentiful, there was felt small need for cooperation. The cause of failure, as we shall see, was to a large degree, due to the lack of the feeling on the part of people of their need of such undertakings。

(3)

"Cooperation," said Warner, "mong wage-earners in what may be termed the Hiddle West, is as yet almost wholly tentative. He who writes of it must, for the most part, be content to describe hopes and sketch possibilities. His work, at best, must be somewhat like a reporter for a sporting paper on the day before a race; he can state the rules, speak of the condition of the track, mention certain would-be competitors that have been ruled out, describe the favorites, and make as many guesses as his information or self-confidence may warrant." When one looks

(1) Warner, "Three Phases of Cooperation in the West, "Pages 61-66 (2) Ibid: Preface

(3) Ibid, Page 50 
back at the period from 1860 to 1890 , he sees greater success than could be imagined by a writer at the close of the period, but this success was not in practical operations as much as it was a paving of the way for the success which was to follow. (1)

Powderly said in 1885 that, "The great fault with too many cooperators is that they advocated the establishment of cooperative institutions on too large a scale." The most pretentious of these were often the greatest failures. They were bold in planning, but incompetent in practice. The knights of Labor affirmed that they had the goal of universal cooperation (2) in view, but it seemed distant. Some, in and out of the order, expected the Millenium imnediately; The most radical of these believed in "Integral Cooperation." "This is really socialism, with socialized capital and reward for service." Efforts were made, especially on the Pacific Coast, to establish such communities only as are recorded in the Middle Vest. "The object was," advocates held, "the establishment of a community where all the trades should be represented, and by an exchange of products make the nembers independent of all outsiders - a social integer." Henry $\mathbb{E}$. Sharpe, in 1880 , established the "York Society 5. There were about 60 members in 1882 of of Integral Cooperators. There were about 60 members in 1882 of whom some were located on a one thousand acre farm near Eglinton, in the southwestern part of Missouri.

The object was "to form an absolutely independent comunity, not communistic, but with the motto: Equal opportunity

(1) General Proceedings K. of I. 1885, Page 22

(2) General Proceedings $K_{\text {. }}$ of I. 1882, Pages 320-21

(3) Varner, "Three Phases of Cooperation in the West," Page 61 (4) Ibid, Page 62 
(1)

but reward proportioned to deed." Capital was borrowed at interest, but ultimately all capital was to be socialized. The members of the colony entered the local assembly 2776 of the Knights of Labor, and Sharpe was made chairman of the Cooperative Board of the Order. In his lectures, he showed the existing organization of industry a failure, saying that. England had failed and that neither competitive nor productive cooperation would succeed. The solution was to be the union of the two integral cooperators, He said: "Do not produce to sell; do not buy to consume. Be independent of capital, independent of markets and of the price of labor. Work for (2) yourselves."

As Sharpe lectured, the Model Colony was in revolt against him. Charges of dishonesty were made. He refused for a while to return to answer the charges but when finally he did, he was condemed and discharged. The Executive Board returned to Bglinton to find the society a wreck. Only two families were left and they distrusted each other and Sharpe. Couses

Causes for failure were assigned as follows:

1. City people cannot succeed in cooperation at once.

2. Want of individual incentive for exertion.

3. Want of means to discipline or to expel nembers.

4. No way of restraining members in case of a panic.

5. The smallness of the scale on which the experiment (5) was tried.
(1) Ibid, Page 62
(2) Ibid, Page 63
(3) Ibid, Page 63
(4) Warner, "Three Phases of Cooperation in the West," Page 64 (5) Ibid, Page 66. 
The causes for failure were lessons to be learned. Many. continued to look on this form of cooperation for success. (1)

Mr. John Samuels in his pamphlet "Hov to organize Cooperative Societies," agreed with Sharpe when he said, "The object of this society is to elevate the intellectual, moral and financial condition of its members, through cooperative efforts; and in accordance with the following plans and arrangements:

1. "The establishment of a store to conduct the business of general dealers, wholesale and retail, in food, clothing and other cormodities; and to manufacture the same whenever practicable, or when necessary for the employment of such members as may be suffering from an undue reduction of wages.

2. The buying and holding of land, and the erection of buildings thereon for the use of the society.

3. To elevate the domestic conditions of its members by buying a building suitable for homes for such as may need them.

4. The purchase or rental of lands or landed estates, to be cultivated by members who are out of employment, or. who may suffer from poor wages.

5. And to proceed, as soon as practicable, to the establishment of a self-supporting home colony, or to assist other societies in establishing such colonies, wherein may be exemplified in a practical way the cooperative idea of production, distribution, education and government."

(1) Ibid, Page 66 


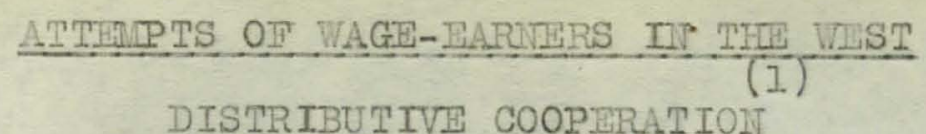

The year 1881 marked the earliest attempt by. wage(2)

earners at cooperation in the West. A vast number were coning, or trying to come, into existence then. Information concerning these attempts before 1886 is meager. Thirty or more are described.

The nost interesting feature of the beginning of cooperation in the western states was the methods used in getting started. A circular was issued fron Cincinnati, Ohio, January 1886, containing the following:

(3)

"Cooperation Fair; Fannie AlIyn, I.A. 44.57, Cinn.

Believing that our only salvation lies in cooperation, and that being one of the leading principles of our noble order, we, therefore, having full confidence in each other, make a bold. attempt in forming a cooperative concern.

I.A. 4457 has announced that a fair is to be held at I. of I. Hall, Southeast Corner of Abigail and Main Sts., for said purpose, commencing Iarch 21 ending March 28th.

We would like all cooperative concerns to correspond with us, and give statements of articles manufactured and prices thereof. We will be thankful for any information of the above description, as we are anxious to exhibit $K$. of $I$. goods manufactured or made by members of the Order.

We have enclosed tickets for various articles to be raffled for at said fair, and we hope the Assembly will use its (1) Warner, "Theee Phases of Cooperation in the West, "Pages 67-82 (2) Ibid, Page 67

(3) Ibid, Page 69 
influence in the disposal of the same.

All articles raffled off will be made public through the journal and the labor papers of the country.

A11 remittances to be made by March 15 th.

$$
\begin{aligned}
& \text { C. Fanny Allyn } \\
& \text { Geo. C. Kuechler } \\
& \text { Iiss Maxy Healy }
\end{aligned}
$$

\section{Fair Committee."}

Such a scheme was too slow to satisfy the ideas of the cooperetors as to what should be achieved. In explaining the simplioity of cooperation, Mr. Trevelleck, in a lecture in Cincinnati, had exolained how cooperation might be begun in the cooperative purchase of a box of soap. The leaders were to learn tiat a successful cooperation was nore complicated than this.

Geo. C. Kuechler, a shoe cutter, was the moving spirit (])

in the order. Out of eighteen nembers of the local assembly, twelve were ladies. Motices of the fair were printed in distant papers as this was the first cooperative undertaking of its kind. Friends sent in donations and a large number were represented in exhibits. Among the most prominent exhibitors were, The Richmond Cooperative Commercial and Menufacturing Soap Company, Richmond, Va.; The Ohio Valley Cooperative Pottery Company, Tiltonville, Ohio; The Quaker City Cooperative Carpet Co., Philadelphia, Pa.; Canmakers' Irutual Protection Association, of Baltimore, Md.: Cooperative Moracco Nanufacturing Co., Philadelphia, Pa.; Kentucky Railroad Cooperative Tobacco Co., Covington, Ky.; NationaI K. of I. (1) Warner, "Three Phases of Cooperation in the Vest," Page 70 (2) Ibid, Page 71 
Cooperative Smoking Tobacco Co., Raleigh, Ir.C.; The Cooperative Corn-Cob Pipe and Iovelty Works, of St. Charles, Mo.; The Cooperative Hat Company of South Iorwalk, Conn.: The Cooperative Cooper Shops, of Mirn.; also by Phoenix, Morthwestern, Morth Star Hennepin and Minn. Barrels were sent made from select staves and hoops elaborately painted and varnished, filled with "Pillsbury's Best" flour made by Pillsbury IIIling Company. Iiquor was not sold, it being against the rules of $K$. of $I_{\text {. organizations. }}$ Business began Ilay lst after name was changed from Fannie (1) Allyn to $\mathbb{K}$. of I. Cooperative Association No. I. The company resembled that of a secret society. Initiation fees were placed. at $\$ 15.00$ to be paid in advance or one might allow dividends to accumulate. Fifteen cents a month was assessed as dues. The fifteen dollars were never returned and membership was not transferable. Goods were sold at regular rates and profits divided among members after a reserve fund was provided. In case of dissolution, the General Assembly was to receive the permanent capital.

At the beginning they were able with the fair, initiation fees, accumulated dues, to buy a stock of goods of $\$ 504.00$ and have a reserve fund of over $\$ 150.00$. Rooms were rented at $\$ 3.50$ per month and business hours were to be from seven to ten Pollo, members offering themselves as managers free of charge for the first quarter. Without much business and amid quarrels the association was still in existence in 1886. Dividends were declared at $3 \%$ the first quarter. For some reason Ir. Kuechler was not connected (1) Ibid, Page 73 
with the firm in 1886. Perhaps because he was not in hamony with the ideals of the organization. The Knights of Labor compelled them to drop their name from the organization.

\section{(1)}

\section{ITATIONAI COOPIRATIVE GUIID}

Another association known as the National Cooperative Guild was begun by Mr. Kuechler of the Association Mo. 1. The Preamble to the constitution makes clear the character of the (2) enterprise: "It is deemed advisable to establish a cooperative distributing association, based on a plan as indicated in the following pages; which, it will be seen, differs somewhat from the prevailing European wholesale distributive stores, as depicted in the Statistics of Labor Bureau, 1886.

ahe various existing wholesale stores in Europe seem to be the outgrowth of numerous cooperative retail stores; and are a creation of the several retail stores.

"There being no such stores established in our vicinity, we are necessitated to adopt a system suitable to the individual stores as they are; at least for the present.

"However, we favor the establishnent of cooperative retail stores as opportunity in time will admit. Out most useful cooperative work in its commencenent, perhaps, will be to șecure an extended market for a great number of productive cooperatives, as they are looming up promiscuously, by purchasing from them, and pushing their various commodities into the consumers market, thus securing a demand and market for the same which otherwise they noy never find."

(1) Warner: Page 74
(2) Toid, Page 75 
Capital was small, but ten cooperative.enterprises were fostered on the consumers basis in 1886. One of the most difficult things for some companies was finding a market. Advertisting, which is a great.factor in business of this nature, was omitted. Thomas Kuechler, who was a traveling. salesman, was a great aid to seliing.

The Streator Cooperative Society:

This was a chapter of the Guild and had to do for the most part, with the curiosities of cooperation. Its failure gives us a conception of the causes of fallure in cooperation and had caused us to realize the limitations of the attempts at cooperative enterprises.

This enterprise began in 1885 and met with immedite success. The attention of wage-earners was attracted and labor papers gave accounts of it. Requests cane from others for copies of the constitution. Its origin come from Joln H. Shay, Iecturer for K. of L. He was elected President of the company. Stock was held largely by wage-carners of the Knights of Labor. Efforts were made not to antagonize other dealers who did not come into conflict with the store. Capital stock was \$5000 in $\$ 10$ shares and no one allowed over five shares. Strict mies held the membership in close bounds. Twenty-five cents was charged for admission to membership. Shares were paid all at once or at the rate of $\$ 1.00$ per month, dividends being allowed after first payment. Six percent dividends were paid if profits permitted. When interest was paid, $20 \%$ was set aside for reserve fund. Wine directors controlled, elected by the officers. "We employ," said

(1) Warner, "Three Phases of Cooperation in the West," Page 76. 
Shay, "eight clerlos in the store and two teamsters to deliver goods, and have lately put in a patent cash carrier. The store is located in the heart of a thriving town of 15,000 people, and is in no more danger of failure than the ocean is of goind dry, and we are as certain to have dividends as people are to eat, wear clothes and use tools."

The Iemarie Cooperative Association and others:

This association, located at Lemarie, Wyoming, was a model for quite a number of enterprises. For over five years it was a success. The association was incorporated December 2I, 1881, with a capital limited to $\$ 30,000$ of $\$ 5.00$ shares. No one held more than 20 shares, though there was no limit to number that could be held. Stock was not assessable and each member was allowed one vote only. Mo member who was in debt to the association two days prior to any meeting was allowed to vote. "Profits shall be divided as follows: 1. After deducting all expenses, interest, at the rate of $12 \%$, shall be paid on share capital. 2. Irembers shall receive the full dividend on cash purchases and one-half the dividends to known non-members on their cash purchases." In 1886, no dividends had been paid. However, begiming Dec. 1, 1886, the association proposed to pay dividends in order to stop the increase in the value of shares. The number of shares had increased to 114. Mo more shares were to be issued after Dec. 31, 1887. It was expected that the $\$ 30,000$ would be subscribed by that time.

H. Breitenstein, President of the company for two years made the following Seventh Semi-Annual Report as business ma.nager:

(i) Ioid, Page 78 . 
Goods to the amount of .................. 073.91

Stock to the amount of....................... 959.90

Rea. Estate to the amount of...... 11,700.00

Open Accounts " "

Notes in our Pavor " "..... $2,558.50$

Ironey in Safe, Dec. Ist............ $\frac{166.50}{144,326.94}$

Amount capital stock taken to date $7,820.00$

The Cooperation is worth todey independent

of al1 debts and capital stock.....10,131.09

Total worth of Association.......317,951.09

This is success in spite of high interest. Some haIf dozen other enterprises of similar nature were undertaken in the West. Two in Wyoming, one at Evanston and one at Carbon, one at Eagle Rock, Idaho; another at Denver, Col.; two in Kansas, at Ellis and Leavenworth; another is spoken of at Green River, Wyoming. Al1 these began during 1885 or 1886.

The Colorado Cooperative Mercantile Association of (1)

Denver, was the most successful. Incorporated in 1885 with stock Iimited to $\$ 25,000$ in $\$ 10.00$ shares, it had 122 shareholders who held \$2,500 worth of shares. After all expenses were paid, paid up capital was allowed 5\%, the remainder of profits going to purchases, the shareholders being allowed twice as much as others. At the end of the first quarter a $4 \%$ profit was declared on purchases by members and $2 \%$ by non-members. Cards were provided whereby purchases could be indicated by punches. Three clerks were employed and business was reported to be growing repidly. Support cane mostly from railroad men. Mr. Thomas Measham, wrote in 1886 , that the chief hindrance vas that of the ourchaser taking too much advantage of the thirty days credit system. Merchants who predicted the store would die in six months tried to aid the realization of their predictions.

(1) Warner, "Three Phases of Cooperation in the West, " Page 81. 


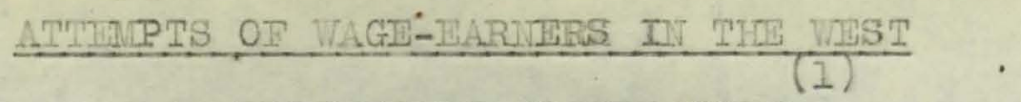

\section{PRODUCTIVE COOPIPATIOIF}

Being quick to see the limitation of distiobutive cooperation, the wage-eamers of the vest tumed their attention to productive cooperation. In over twenty industries attempts were made to introduce this fom of cooperation. Some were successful while a large number died shortly after the project began. Warner, in his "Three Pliases of Cooperation in the West," gives a table of these enterprises. "Some," he said, when writing in 1886, "are alroady dead, but the history of each is well worth knowing." A list of the more important ones are noticed.

1. Cooperative Baking Powder Co, Elkhart, Ind.

2. Cooperative Box Factory, Cincinati, Onio.

3. Mational K. of I. Cooperative Broom Co., Cincimati, Ohio. 4. Carpentering:

(a) Carpenters Cooperative Association, Decatur, III.

(b) Cooperative Sash and Blind Factory, Rusinville, Ind.

5. Clothing Factories:

(a) Our Girls' Coperative Clothing Manufacturing Co., 151 W. Market St., Chicago, III.

(b) Manufacturing Tailoring Co., Chicago, Ill.

(c) Nartha Washington Cooperative Overall and Knit Work Association, Indianapolis, Ind.

6. Cooperst Cooperative Assodation, Detroit, Ilich.

7. Expressmen, Detroit, Mich.

8. Foundrynen's Cooperative Mlanufacturing Co., Chicago, Ill.

(1) Wamer, "Three Phases of Cooperation in the West, "Pages $82-102$
(2) Toid, Page 82 
9. Purniture Workers:

(a) Cooperative Reed Chair Factory, Michigan City, Ind.

(b) Mechanics' Furniture Association, St. Louis, Mo.

(c) Central Fumiture Co., St. Louis, Mo.

(d) Furniture Workers Association, St. Louis, Mo.

(e) Cooperative Furniture Co., Cincimati, Ohio.

10. Cooperative Match Factory, Indianapolis, Ind.

11. Mining:

(a) Cooperative Cos.I Co., Bloomington, Ill.

(b) Cooperative Iining Co., Fairbury, Ill.

(c) Cooperative cioal Co., Peoria, IIl.

(d) Union Mining Co., Connelbury, Ind.

(e) Cooperative Mining $C_{0}$, , Fountanet, Ind.

(f) Cooperative Mining Co., Huntsville, Md.

(g) Summit Cooperative Coal \& Mining Co, Macon, Mo.

12. Mail Mills:

(a) Steubenville, Ohio.

(b) Iron \& Steel Maid Works, Bellville, Ill.

(c) Wellston, Ohio.

13. Cooperative Packing \& Provision uo., Chicago, Ill.

14. Cooperative Corn-cob Pipe Co., St. Charles, Mo.

15. Planing Mills:

(a) Tast Side Planing Mill, Kansas City, Mo.

(b) Mechanics' Planing Iilı, St. Louis, Mo.

16. Pottery Works:

(a) Potters' Cooperative Co., Hast Liverpool, Ohio.

(b) Standard Cooperative Pottery Co., East Iiverpool, 0.

(c) Ohio Valley Cooperative Pottery $C_{0}$, Tiltonville, 0. 
17. Publishing Companies:

(a) Publishers of K. of I., Chicago, III.

(b) Cooperative Publishing Co.j Sandia, Kansas.

(c) Publishers aTrade-Union", Atchison, Kansas.

(d) Publishers Daily "Evening Star", Bay City, Mich.

(e) Publishers "Inaustrial Irews", Toledo, Ohio.

18. Boot and Shoe Cooperative Association, Detroit, Mich.

19. Somp Works:

(a) Assemblies' Cooperative Soap Co., Toledo, Ohio.

(b) I. of I. Cooperative Soap Co., Chicago, IlI.

20. Stove Works:

(a) Cooperative Stove Co,, Bloomingtom, Ill.

(b) Western Stove Works, Peoria, III.

(c) Westem Stove Manufacturing Co., St. Iouis, Mo.

21. Cooperative Tile Co., Cable, III.

22. Tobacco Factories:

(a) Cooperative Cigar Factory, Lafayette, Ind.

(b) Cooperative Cigar Co., Delaware, Ohio.

Some of these were dead in 1886. Each had a history worth linowing. llost were living and vere said to be prosperous. A treatment of the most prominent is given.

\section{IINING COMPAIIES}

1. Union Irining Company, Connelbure, Ind.

In 1883 certain men at work for the Buckeye Mining Co. joined I.A. 1436 of K. of I., and were in consequence discharged. They had credit enough to borrow $\$ 2,000$ with which they sunk a shaft

(1) Varner, Page 84. 
near the Buckeye works. To meet their rates when maturing, they appealed for help to the order of the $K$. of $I$, and on Iarch 3, 1884, the Executive Board made a plea for them. "Powderly, at that time, less experienced, and more hopeful then since, wrote as follows:

"Can anything be done for our Connelburg brothers? If no other plan presents itself, levy an assessment or issue an appeal - anything to preserve them. The money is vell invested; really it is the first sensible nove that has been put into practical operation. These men are locked out, and instead of sittine down and sucking their thumbs in idleness, awaiting assistance from the Order, they go to work and flank the enemy by entering into competition with him. Let them have the assistance fund, the cooperative fund - only dontt let them fail. It will be the biggest card for the.order we ever played. Count on my entire and hearty cooperation in anything you may do for them."

I. A. 300 advanced the $\$ 2000$ needed and the enterprise was incorporated. Ten thousand dollars was raised by the issuing of two thousand debentures of five dollars each, taken by nembers of the assemblies or by assemblies as a whole. Proceeds of the mine were divided, (1) Current wages to laborers, (2) Incidental expenses, and (3) Tive percent interest to debenture holders. If any profits remained they were divided so that ten percent should go to the general cooperative fund, ten percent to the sinking fund for the purchase of debentures, three percent to the local educational fund, and seventy percent to be divided equally between labor and capital, "in proportion to value of investment." A cooperative store was anticipated 
in connection with the mine. Everything seened to promise immediate success.

A switch had been built from the mine to the Ohio and - Ilississippi railroad and Ir. Peabody had promised to comnect the switch with the main road. The old Buckeye Company was able, to control the rsilroad to the extent that the attempt of laborers was hondicapped considerably. The cost of court proceedings to force the carrying of cool by the railroad. was too expensive. Nothing remained but to sell out at any price. This is a fair sample of railroad discrimination against wage-earners. It was to prove a great hindrance to any effort at cooperative production.

(1)

2. At Fairbury, Ill., there was a strike of miners in the spring of 1886. They sunk a shaft and began talking coal out for themselves, securing nost of local trade. The railroad company refused to build a switch and the miners were unable to undertake so wuch expense and, even if they should, the company might refuse to haul the coal. "The courts have decided that while a railroad may be compelled to haul freight, it cannot be compelied to furnish cars." Failures like the above caused the labor papers to declare that "justice is becoming a Iurury wilich the poor camot afford."

(2)

3. Fantanet, Indiana, was the scene of a most disheartening failure among wage-earmers. The Cooperative Mining Company of this place went to pieces, after a quarrel among its members, leaving liabilities at $\$ 10,000$.

(1) Warner, Page 86

(2) Warner, Page 84 
4. The largest mine at Huntesville, Mo., after being deserted for five months in consequence of a strike, was taken over by mincrs, who, using the company's tools, paid a royelty to the company of one cent per bushel.

$\cdot$

5. A compeny at Peoria, III., was reported as prospering with a capital of $\$ 20,000$.

6. Two mining companies were conspicuously successful. One, locsted at Bloomington, IIIinois, was incorporated July 18, 1885, with a capital of $\$ 30,000$. Iike others it originated by dissatisfaction with wages and treatment received from an established company. There was mucli rejoicing when the first load of coal was dravm from the new shaft and this first load was repeatedly auctioned off, bringing a total of $\$ 505.00$.

The company was simply a joint stock concern. Thirty shares were held by twenty-two men, all working in or about the mine except two merchants who desired to hold the good will of the miners. The president was very optinistic about the company in 1886, as it held a lease of several hundred acres of coal land on which they expected to sink shafts. The railroads seemed favorable toward them.

7. The Sumit Cooperative Coal and Iining Company, near Bevier, Nacon County, Mo., was incorporated in July 1885. The imnediate cause of its formation was a strike against the old
(1) Ioid, Page 84
(2) Ioid, Page 84
(3) Ioid, Page 84 
company because it employed a negro. Capital stock of $\$ 5000.00$ was held by 150 persons in $\$ 10.00$ shares. In 1886 the company held the lease of two mines, giving claim to 450 acres of coal, 130 acres of land, and 36 tenement houses. Work was plentiful and wages high in the winter season. Profits were great in spite of high wages. There was work for 250 men in the winter and 140 in the summer. Even the workers who were not shareholders submitted to $5 \%$ deduction from their nominal wages, which was added to the profits of the company. No profits were to be allowed until the company had $\$ 12,000$ net profits. The annual product was valued at $\$ 85,000$. Dealers at a distance found it profitable to advertise that they kept the "Bevier Cooperative Coal."

\section{FURNITURE MAKERS}

1. A company of strikers organized the St. Louis Furniture (I)

Workers' Association in 1878 and began a prosperous career. Two hundred and eighty shareholders held shares at $\$ 25.00$ each. Ninetysix of the shareholders were laborers and by February 1, 1886, they had given up $10 \%$ of their wages to buy outside shares. No person was allowed to hold more than 20 shares. The Executive Board made the purchases and sales. Wages were regulated by a committee appointed for that purpose. Part of the men were paid by the week, wages ranging from $\$ 12.00$ to $\$ 15.00$ per week. A dividend was declared in 1884. All the stock was taken by 1886.

2. Ihe capital stock of $\$ 30,000$ of the Central Furniture Company which began operation in St. Louis in 1881 was paid up by 1886 .

(I) Warner, Page 90

(2) Ibid, Page 90 
Shares were $\$ 100$ each and there was no limit as to the number a person could hold. About four-fifths of the fifty persons who held stock worked with the company. At the end of the first year, a passable $6 \%$ dividend was carried to the reserve fund. A dividend of $45 \%$ was declared the second year but only $35 \%$ was paid, and this in stock. 1884 a dividend of $20 \%$ was declared and $5 \%$ paid in cash and the rest in stock. In 1885 no dividend was paid.

3. A third enterprise of this kind was the Mechanics' Furniture (1)

Association of St. Iouis, which began operation in March of 1885 . The capital stock was $\$ 25,000$ of $\$ 50.00$ shares each, held by 150 persons, 65 or 70 of whom were workers. Nine directors looked after the wages; three trustees looked after the finances, while the President made the purchases and sales. Ien percent of the wages were held out and dividends were to be paid in stock until it was all taken.

4. The Cooperative Furniture Company, of Cincinnati, Ohio, was incorporated July 13, 1886, and began work on the 25 th of the following october. The immediate cause of the formation of the company was the failure of an "Eight-hour strike." The stock of $\$ 50,000$ was divided into shares of $\$ 100.00$ each. Each member of the company was compelied to hold the same number of shares. The last of January, 1887, $\$ 34,500$ of stock was taken by 69 persons. Fifty-one men, all of whom owned stock, were employed. Profits to be divided among shareholders.

5. August 14, 1886, the Cooperative Reed Chair Factory, of Michigan City, Indiana, was organized because the old factory began
(1) Ibid, Page 91
(2) Warner, Page 91
(3) Ibid, Page 92 
to use convict labor. Capital stock was placed at $\$ 50,000$ of $\$ 5.00$ shares. The value of the annual product was estimated to be about $\$ 25,000$. In 1887 , there were 500 shareholders, 42 men worked in the factory, all of whom owned stock except eight miners. Profits were to be divided according to shares held.

Mr. Warner wrote in 1887, "On the whole, it may be said that results have been obtained in this branch of industry, as substantial as those in any of the others."

\section{PLANINTG MTILS}

1. With a nominal capital of $\$ 50,000$ but with a supply of available cash of only $\$ 10,000$, the Mechanics' Planing Mill Company began operation in 1874. The company was cooperative only in practice. Transferable shares valued at $\$ 500$ were issued to outside parties or workers for cash or script. At first there were 25 or 30 stockholders, about three-fourths of whom were laborers. The officers made purchases and sales and a board regulated the wages. For a long time the company was handicapped because of inadequate capital. The credit of the company was very poor. At one time it vas refused ten feet of belting because cash did not accompany the order. In the second year a fire caused a loss of $\$ 8,000$. They managed to get lumber on credit, and the stockholders put up the building. After this, success seemed to come, and in 1884 all the stock was taken. In 1887 they had an undivided surplus of $\$ 35,000$ and the shares were worth double their face value. Dividends were usually paid at 10\%. Wages for piece work was a trifle higher than at other places.

(1) Ibid, Page 92 
The above concern was merely a profit sharing enterprise, that is to say, the feal control came from the superintendents. This was more true of the East Side Planing Mill of Kansas City, Mo. Although this was spoken of as a cooperative enterprise, it was in reality a profit sharing organization under the management of $V$. W. Coddington.

\section{CARPENTER INTG}

1. The Carpenter' ' Cooperative Association of Decatur., Illinois, was incorporated in 1885, with a stock of $\$ 5,000$ held by 18 persons in $\$ 10.00$ shares. Profits were to be divided according to shares but the company proposed to pay larger wages than competing firms. Twenty-three thousand dollars worth of business was done the first quarter and labor papers seem to indicate that the company was prosperous in $188 \%$, according to Ifr. Warner.

(3)

2. The Cooperative Sash and Blind Company began operation in 1886 with six men in their employ. No definite information could be gathered as to the success of this concern.

\section{STOVE WORKS}

1. The Cleveland Cooperative Stove Company was incorporated in 1867 and was for a long time thoroughly cooperative dividing the profits with the laborers. A long fight was made to keep it going, but it was found that under the managerent, enough capital could not be secured. After being practically closed for two years, it was resumed as an ordinary stock company, with a good deal of the stock
(1) Warner, Page-93
(2) Ibid, Page 94
(3) Ibid, Page 94
(4) Warner, Page 94 
being held by the employes. The capital in 1887 was $\$ 250,000$ in $\$ 100.00$ shares. Of the 350 men employed, about 90 were stockholders. The value of the annual product was about $\$ 400,000$. Profits were divideà according to shares. A branch house was established at St. Louis.

2. A Cooperative Stove Company was begun in June, 1886, at Bloomington, Ind. A strike proceeded its formation, caused partly by low wages and partly by the fact that the company worked men for only about half the year due to the volume of business done. A capital of $\$ 12,000$ was subscribed by 40 stockholders in $\$ 10.00$ shares, no one being allowed more than 100 shares. A circular appeal was made to the $K$. of $I$. and assemblies subscribed $\$ 4000$ of the stock. Profits were divided according to stock held.

\section{Pottery and Tile Works}

1. A favorable opportunity was offered the wage-earners of East Liverpool, Ohio, to purchase and begin operation of a Pottery Factory. As a result of their efforts to secure work for the stockholders as well as profits, the Standard Cooperative Pottery Company was incorporated August 18, 1886, with a capital stock of $\$ 20,000$ in forty shares held by thirty-four persons. No person was allowed more than two shares and one vote was given each member. Forty-four men were employed, of whom twenty-six were shareholders. The annual product was $\$ 70,000$. After 1887 the company predicted it would be able to declare profits as the works would be paid for in that time.

2. The Ohio Valley Cooperative Pottery Company, "Manufacturers

(1) Ibid,Page 95

(2) Ibid, Page 95

(3) Warner, Page 96 
of Rockingham and Yellow ware, terra cotta hanging baskets, flower pots, etc." was organized November 18, 1885, with a paid-up capital of $\$ 4000$ held by twenty-six individuals. The number of men employed were from 16 to 18 and perhaps a majority did not hold stock. The company was only mildly cooperative.

3. After the feasibility of such an undertaking had been discussed by the local assembly of the Knights of Labor, the Cooperative (1)

Tile Company of Cable, Illinois, was organized in March 1886, with a capital stock of $\$ 4000$ in shares of $\$ 15.00$ each held by 23 persons. The annual product was $\$ 15,000$. Eighteen laborers were employed and dividends were divided according to capital invested. No member was allowed to hold more than 12 shares and only one vote was given each holder. Lack of sufficient capital hindered the business greatly.

\section{CLOMHING FACTORIES}

Two enterprises of this nature had been undertaken in the West before 1887. The Knights of Labor, as a rule, rallied gallantly to the help of this class.

1. Our Girls' Cooperative Clothing Company received especial encouragement from labor papers and from local assemblies of the Knights of Labor. The girls comprising this company were locked out for taking part in a parade sept. 6, 1887. "Being afterwards blacklisted it become a question of cooperation or starve." The $\$ 10.00$ shares needed to secure capital for this enterprise were liberally subscribed by the Knights of Labor, and it was the intention of those interested to fit up a room with 20 or 30 machines for the manufacture of ready-made clothes.
(1) Ibid, Page 96
(2) Ibid, Page 97 
2. Mr. Warner in his "Three Phases of vooperation in the West," says that the most tastefully printed copy of by-laws and constitution come to him from the Martha Washington Cooperative (1) Association, which was organized for the manufacture of overalls, shirts and knit goods. The nominal capital was $\$ 10,000$ in $\$ 5.00$ shares. Each girl who became a member could pay fifty cents per. share and twenty-five cents per week until the shares were paid. "Each male stockholder shall pay one dollar per share, and fifty cents per week for each succeeding week." None but members were to be employed and normal wages were to be paid. Ten percent of the profits were to go to the reserve fund and the remaining of the dividends were to go to stockholders in proportion to work done. All the officers were women.

\section{OTHER INDUSTRTES}

1. The Boot and Shoe Cooperative Association of Detroit, organized in Sept. 1885, had a hard fight for existence. Of the $\$ 50,000$ of nominal capital, $\$ 1800$ was paid in by 1887 . The organization, though fully cooperative, teaches us that capital vill not be invested in an enterprise when there is nothing more luring than a low rate of interest.

2. An advertisement in the Knights of Labor Nagazine, December 18, 1886, announced that $\$ 30,000$ of a $\$ 50,000$ project to establish the Chicago Cooperative Packing Company was already subscribed. The advertisement also stated that "The business will be capably and
(1) Warner, Page 98
(2) Ibid, Page 98
(3) Ibid, Page 99 
economically managed without risks, and depending on regular profits through a continuous chain of interstate union markets. The establishment will employ union men only, and run on the eight-hour plan." "It seems very doubtful," says Irr. Warner, "if much meat will be packed by this company."

No mention is made of "Communistic Societies, nor of the "building associations." Insurance companies, claiming to operate on the "Cooperative" or "Mutual" plan are said to have existed. throughout the West. 


\section{COOPERATIOIN IN THE IORTHWEST}

(1)

(2)

1. Cooperation of Iinnesota:

The cooperative attempts of the coopers of Hinneapolis.

will serve to illustrate the success of cooperators of Minnesota. liany (3) things lent to the success of cooperation in that city. The rapid growth of the city, the railroad system, being one of the best; the eminence of the city as a wheat market; its great lumber trade; its magnificant water power and its large flour industry all added to the attractiveness of the city. It is the flour trade that was of chief concern to the coopers. Millions of barrels were used annually. Seven or eight hundred coopers furnished the barrels for the flour and a majority were grouped in small cooperative shops at the end of the period.

In the Spring of 1868, William H. Reeves, George W. Sargent and Joseph Combs were persuaded by an intelligent young journeyman by the name of C. W. Curtis, to join him in a cooperative experimento They began very simply, with no organization. Each had his kit of tools. They rented a shop and purchased a small amount of barrel material with which they began to make barrels at a certain price. Each was allowed a certain wage for work and the humble profits were divided among the four. For a few months the business prospered, but came to an end when there was no longer a demand for barrels because of the closing down of shops. They sold out to a boss cooper who had a contract with a company to furnish barrels, and became workers in his shop.

(1) Albert Shaw "Cooperation in the Northwest." (In Bemis, "History

(2) Ibid, Page 199

(3) Ibid, Page 199

(4) Ibid, Page 203 
One Friday in the Spring of 1870 , the journeymen in the shop where Gurtis was working learned that their wages were to be cut from fifteen to twelve and a half cents per barrel. Monday morning found Curtis and others at work in a shop of their own with a contract for four thousand barrels. With a capital of less than one hundred dollars, they prospered, giving work to as many as three other journeymen. Soon a contract was in sight for a large contract for barrels, but one member of the firm secured the contract and announced himself as a boss contractor. This ended the second attempt of coopers at cooperation.

In 1874 the Cooperative Barrel Manufacturing Company was (1) organized by the same Curtis and others. This attempt became the parent of the other cooperative attempts in IInneapolis. The amount of capital stock was placed at $\$ 10,000.00$, of which fifteen percent was to be paid when subscribed. Indebteaness and liability were limited to $\$, 500 \cdot 00$. Officers were to be elected annually by the stockholders. All the essential features of the by-laws remained the same. Among the most important features to be noted by the (2) reader of the by-laws are those which provided that all members must be equal shareholders, and that the ordinary gains or losses of the business was to be apportioned, not pro rata among the members, but in proportion to the work they had done. This was a distinctive feature of cooperation. Soon the company prospered to such an extent that larger quarters were necessary. These were secured and the work went on. It is interesting to note the anxiety of the members when they were ask to pay the fifteen dollars to the treasurer for membership, for fear he would leave with the money. They had to trust him,

(1) Shaw, "Cooperation in the Northwest," Page 207

(2) Ibid, Page 208 
however, as he was unable to make bond. There is no record, with one exception, that a treasurer was dishonest with funds intrusted to him, though as much as twenty-thousand dollars came into the hands of the treasurer at a single instant. This company maintained a membership of ninety. The president, Mr. II. J. Gill, gave out a report in 1886, 'that the company's real estate was valued at $\$ 23,000$, that it owned a stave factory in Wisconsin worth $\$ 25,000$ and that it had on hand materials and manufactured stock to the value of $\$ 10,000$ making total assets of $\$ 58,000$. Liabilities of all kinds amounted to \#13,000. Fully fine-tenths of the stockholders owned their own homes. This company seems to have been one of the best cooperative concerns in the country.

This company is a fair sample of the many other successful attempts on the part of coopers at cooperation. Among the other (2) companies were: The North Star Barrel Company, The Hennepin County Barrel Company, The Phoenix Barrel Nanufacturing Company, The Northwestern Barrel Company, The Acme Barrel Company and The Twin City Barrel Company.

2. Cooperative Profit-Sharing in the Pillsbury Mills:

The firm of Charles A. Pillsbury and Company was the largest (3) flour manufacturing company in the world. No employers were more highly regarded by their workingmen than were the Pillsburys. The house prospered and the employes prospered with it.

At the end of the milling year, September 1, 1882, Mr. Pillsbury determined to attempt experimentally a plan of profitsharing which had for sometime been taking form in his mind. He wrote a letter to a selected list stating that an apportionment of

(1) Ibid, Page 217

(2) Shaw, "Cooperation in the Northwest," Page 219

(3) Ibid, Page 255 
the profits would be made to the men who remained during the year, after the interest on capital was deducted. Each man was urged. to be of as much use to the company in saving as possible.

The men could not imagine the amount they would receive at the end of the year, but we can imagine their surprise when each received a check averaging four hundred dollars, at the end of the year. Fach man received a sum equal to a third of his annual (1) salary. For the next two years about the same amount was distributed. However, in 1886, a letter was sent out stating that no profits could be given as there were no profits made. This was because the milling crop was unprofitable in 1885. The flour had gone below the price paid for wheat. Mr. Pillsbury stated that he purposed to continue his practice.

This was on advance in the direction of solving the labor problem. But such had its problems to be solved. There is the workman who grows careless. Then when a man is dismissed from a profit-sharing establishment, it is counted as a disgrace, and more coment is heard from the discharge of a under these conditions than if it were done in the ordinary concern.

The Minneapolis Cooperative Mercantile Company, which was begun in September 1885, was beginning successfully and was mun on pretty near the same principles of other cooperative stores. The organization of the Dundas Coopers, of Dundas, Rice County, Minn., was very much on the order of the Minneapolis organizations. This organization was perfected January 1, 1886. Cooperative attempts anong laundrymen and painters were not uncommon in the Northwest.
(1) Ibid, Page 257
(2) Ibid, Page 259
(3) Shaw, "Cooperation in the Northwest," Page 262 


\section{ATT MPTS}

\section{COOPIRATION IN THE MIDDIE STATES}

(1)

Edward Bemis, in his treatment of cooperation in the Middle States, gives an account of eight attempts at distributive cooperation, eight attempts at productive cooperation and eight attempts at profit sharing. These attempts are treated at length and are traced from their beginning to 1886 or to the time of their failure. We shall give four of each which are enough to give a glance into the efforts on the part of laborers at cooperation in the Iid dle States.

1. Distributive Cooperation.

The first effort at distributive cooperation in the Middle States was on December 16, 1862, when the Union Cooperation Association No. 1, of Philadelphia, was organized. This store was fashioned on the Rochdale system and seens to have been the first store in America organized according to that plan. The store was opened April 1864, with twenty-three nembers. Dividends on trade and all the familiar principles of English cooperation were adopted. Sales increased rapidly, and a business of $\$ 7,751.34$ was done the first quarter. The expenses were greater than profits and. the store was forced to close. Its record was not entirely a failure as the news of this store spread far and wide and many other attempts came as a result.

The Sovereigns of Industry established many stores in the

(1) E. W. Bemis, "Cooperation in the Middle States," (In

(2) Ibid, Page 141 
(1)

Middle States but they did not last because of extravagant expenses, mistaken nethods, incompetent managers, and, chief causes of all ills, jealously and ignorance anong cooperators who would not cooperate.

2. The Philadelphia Industrial Cooperative Society.

This company was one of the largest cooperative societies in this country. It was organized in 1874 on the Rochdale system and did a business of $171,278.04$ in the first twelve years of its existence, divided as follows:

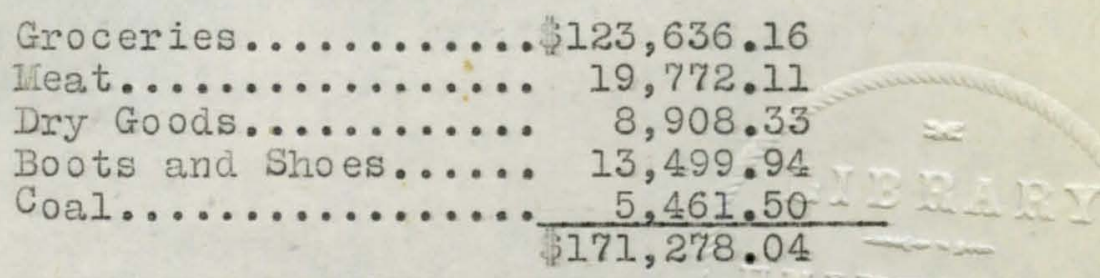

No dividends were declared on coal. On the rest, nembers were paid dividends of $\$ 5,302.10$ and non-members were paid $\$ 764.14$. Ifembers received from three to eight percent trade dividends as business permitted, besides six percent on stock. Trade was exclusively cash. Any mernber could. withdraw all his shares, except five, on sufficient notice to the directors. Shares might also be transferred to any other person.

The capital, in the hands of 2,355 members in 1887 , was $\$ 40,000.00$, half of which was in store buildings and other property. Only groceries were sold prior to 1880 when a Dry Goods department was established. Bad management caused a loss in this department and it was abandoned in 1885. Five percent of the net profits were placed to the account of the reserve fund, which amounted to $\$ 4,500$ in 1887 . The financial standing of the company was excellent (1) Ibid, Page 142 
3. The Trenton Cooperative Society.

This prosperous society began operation on the Rochdale plan on April 30, 1885, with a capital of $\$ 700.00$, and did a business in 1886 of $\$ 49,958.20$ on an average capital of between $\$ 3000$ and $\$ 4000$ in $\$ 5.00$ shares. Very little trusting was done. The total expenses of the company in 1886 was 9.1 percent of the trade, or allowing for the rent the company would have been obliged to pay if it had not owned its own building, 10.2 percent. The moderate percentage of expenses combined with prevailing high retail prices in the city, permitted a dividend during 1886 of $\$ 5,950.42$, or one quarterly dividend of twelve percent, two of fourteen percent, and one of fifteen percent, to members on every.. dollar's worth of goods purchased by them, and half the percentage to non-members, besides paying six percent interest on capital, appropriating $\$ 352.95$ to a reserve fund, \$163.70 to an educational fund, and $\$ 250.00$ to a land fund for the payment of a building purchased for $\$ 10,000.00$ for the store and for other purposes. Because of the remarkable success, the membership grew from 193 at the close of 1885 to 420 at the close of 1886 , and the paid up capital from $\$ 2,430.94$ to $\$ 5,787.12$. "The difference between this store and the scores that have failed lies in the intelligent compre. hension of the members of the real conditions of success." 4. The Brunswick Cooperative Company.

This society, organized August 15, 1881, had a capital of $\$ 3,348.67$ owned by 115 persons in $\$ 5.00$ shares. Evidently the expenses were too great to declare dividends of any high degree, (1) Bemis, "History of Cooperation in U.S." Page 145 (2) Bemis, "History of Cooperation in U.S." Page 146 
since the expenses for wages, rent and incidentals were thirteen percent of the trade. The quarterly dividends of 1886 averaged four percent to members and two percent to non-members. Interest of one and one-half percent quarterly was paid on capital, five percent of the remoining profits were held as a contingent or sinking fund until a sum equal to thirty percent of the capital stock should accumulate. Of the remaining profits, two and a. half percent was placed to the credit of an educational fund to be disposed of by the board of trustees, subject to the approval of the members at any regular or special meeting.

The other distributive cooperative stores mentioned by Bemis are, The Phoenixville Cooperative Society, organized 1885; The ITeshannock Cooperative Society, of Neshannock, Mercer County, Pa., organized 1873; The Kingsland Cooperative Association, of Kingsland, H.J., organized 1884; The fruit Growers Union and Cooperative Society, of Hammonton, IN.J., organized 1884.

1. Productive Cooperation in the Middle States.

The advantage of productive cooperation is that men who share in the profits of the industry will work for the advancement of the industry more than if they are working for owners. One cooperative manufacturing company which was a conspicuous failure is considered, followed by three which existed in 1887. These will serve to illustrate the nature of the many cooperative attempts on the part of wage-earners in the Hiddle States before 1890 . 2. The first cooperative foundry company in America was the Cooperative Stove Works, of Troy, M.Y., founded in April, 1866, as

(1) Ibid, Pages $149-155$ 


\section{(1)}

a result of a strike. The members were ignorant of the principles which safeguard an organization against failure. Out of the profits there was to be paid ten percent interest to stockholders, the rest of the profits were to be divided among the stockholders who worked for the company without regard for the number of shares held. All the stockholders did not work in the foundry and soon those who did voted to increase their wages. Soon those who owned one or two shares increased the price of wages so that no profits could be declared, nor could any interest be paid on capital. This was too much for the large stockholders. Pretty soon the constitution was amended so that votes vere allowed according to shares. Imnediately the wages were reduced by the stockholders and a strike ensued. Though the company existed in 1887, with a capital of $\$ 106,000$ in one hundred dollar shares, it was everything but a cooperative company. Six men owned half the shares. This one fact shows that the men were not able to cooperate. When the plan of dividing the profits was changed and large dividends were declared on capital, two thirds of the stoclcholders became reckless and dissipated, and sold out to the few.

3. The Fulton County Cooperative Leather, Glove and Mitten Hanufacturing Association of Johnstomn, Fulton County, I.Y.

This company started August 12, 1886, and had a paid up capital of $\$ 2,500$ in $\$ 10.00$ shares, owned by two hundred and twenty-five shareholders, before six months of existence. No one could hold more than twenty shares. There was no profit-sharing with employees, profits going entirely to the stockholders, and each stockholder has (1) Bemis, "Cooperation in the U.S." Page 156 
an equal vote. The business was reported as growing steadily in 1886.

4. The Solidarity Cigar Factory.

A new effort at cooperation was begun by Knights of Labor in 1886. This was known as Solidarity Cooperation. Capital was paid in by purely disinterested persons to be used by a committee whose chairman wais held to strict accountability for the conduct of the committee. No shareholder was allowed a vote nor was allowed to say what kind of business should be undertaken. The Committee was directed, under rules, to place twenty five percent for a land fund for providing land for the works, twenty five percent for insurance against loss, and fifty percent for extending the business of cooperative institutions. One of these companies which began operation in 1886 was the Solidarity Cigar Company. This company had \$1,500 capital. Fifty percent wasto be devoted to redeeming the stock on which no interest was to be paid, afterwards to be put to a land fund, the building of factories and extension of other cooperative business; the rest of the profits to be used as an insurance fund and to enlarge the business. This business was reported to be doing good business in 1887.

(2)

5. The Plumber's Cooperative Association was organized October I, 1886, as a result of a lockout in New York. An assessment was levied on every plumber to raise money for the undertaking. Over a thousand dollars was collected. No interest was to be allowed but the profits

(1) Beris, "Cooperation in the Middle States," Page 163
Ibid, Page 163 
64

were to go to aiding others in other towns in getting started. The number employed in the organization during the busy season was seventy, but very much less during other months. Every employed was compelled to own stock as soon as possible. It was strange that such attempts should prove successful, as they were so very different from the old established customs of cooperation: Perhaps it was because the Knights of Labor assemblies supported these att tempts.

Other Productive Cooperative attempts mentioned in the Iliddle States were: The Cooperative Foundry Company of Rochester, IN.I.; The Frankfort Cooperative Manufacturing Company, of Frankfort, Pa.; The Chester Manufacturing Company, of Chester, Pa.; The Reading Cooperative Cigar Company, of Reading, Pa.; The Cooperative Hat Company of Philadelphia; The Concord Printing Company, of Concord, Mass. 



\section{CAUSES OF FAILURE}

\section{(1)}

Bemis, in his "History of Cooperation in U.S." says, "For, after all, the underlying causes of all cooperative failures are lack of intelligence and the spirit of cooperation." All those who speak of cooperation and its failure, come, at last, to suggest that we shall have no great success in any endeavor at cooperative enterprises until we have had a campaign of education and information.

Though there are many other reasons for failure among wage-earners, in their cooperative attempts, we will suggest only a few of the most outstanding.

(2)

1. Lack of Elucation.

The great majority of wage-earners have no high degree of intelligence. They are unable to see far enough into the future to be patient with slow results. They do not know cooperative methods. While they experience slow results ds a result of their ignorance of methods, the experienced and trained mind surges ahead, reaping glowing harvests. Naturally, this brings discouragement to the laborer, who gives up in despair. Though the laboring

(1) Bemis, "History of Cooperation in U.S." Page 25

(2) Coulter, "Cooperation Among Farmers" Page 22 Ford, "Cooperation in Nev Fingland", Pages 27 \& 66 General Assembly Proceedings K. of I. 1886 (Speech of Powderly) 1888, Page 19

Nation 1888, Pages 463 \& 320

General Proceedings K. of I. 1883, Page 401; 1884, Page 607 Warner, "Three Phases of Cooperation in the West" Page 10.1 Powderly, "Thirty Years of Labor" Page 291 Powe11, "Cooperation in Agriculture" Pages 18-39. 
man has become. intelligent in a larger measure, and has come to appreciate intelligence, this was far from true in the period for our consideration. It is interesting to note an article which recently appeared in "Capper's Farmer," owned and edited by Senator Capper of Kansas, in wich he states that the great need of the present day farmer is education in the principles of cooperation.

(1)

2. Leadership.

Fither opposition to educated leaders or the lack of means to employ competent management, kept down the best results in cooperation. In looking over the efforts of cooperators, we find a large number attributed their lack of success or complete failure to incompetent leadership. Bemis said that, "the veakest point in the thinking of laborers and. in the arguments of labor leaders, is that they cannot manage to appreciate the economic value of brains."

3. Iack of Capital.

\section{(2)}

This leads to the fact that cooperative attempts were hampered because of lack of capital. In the first place the

(1) Ford, "Cooperation in New Ingland",Page 66 Powe11, "Cooperation in Agriculture," Pages 18 \& 39

Bemis, "History of Cooperation in U.S.," Page 28

Warner, "Three Phases of Cooperation in the West," Page 101 Powderly's speech in General Assembly 1883

Niation 1888, Page 463

Coulter, "Cooperation Anong Farmers," Page 22

(2) General Assembly Proceedings K. of I. 1880, Page 196; 1882, Page 320

Ford, "Cooperation in New Ingland", Page 60

Coulter, "Cooperation Anong Farmers," Page 23

Powderly, "Thirty Years of Labor," Page 463

Warner, "Three Phases of Cooperation in the West," Page 101 Ford, "Cooperation in New Ingland" Pages 60 \& 66. 
workingman has never had a large surplus of capital. And, in the second place, no man with money was over anxious to turn it loose when nothing more luring than a small interest could be offered. Many operation, opening hopefully, come to find that they lacked funds. Credit was small where there was no very great security. Snall capital, unwisely handled, could not get very far.

4. Jealousy and Strifes.

Until the members of any cooperative attempt are unwilling to advance themselves at the expense of others, we have no hope to hold for cooperation. The laboring man is suspicious, and was more inclined to be of this mind before the end of our period, of his fellow worker. He is lead to distrust his fellows as each learns of the others unsoundness. There is the jealousy on the part of the laborer toward the management, especially if the managers are receiving more wages than he. This, as we have seen above, leads to employment of incompetent leaders. The evidences of strife and jealousy were not to be found exclusively among the average workman. We

(1) Brooles, "Labors Challenge to the Social Order, "Page 258 Warner, "Three Phases of Cooperation in the West," Pages $54 f$ $\& 101$

General Assembly K, of I. 1888 (Powderly's Address) \& 1883. Ford, "Cooperation in New England" (Introduction by Peabody) Powell: Pages 18-39

Powderly, "Thirty Years of Labor," Page 463

Bemis, "Cooperation in U.S." Page 25. 
observe that the leaders themselves are often prone to dispute among themselves. Bad morals are a detriment to any effort at mutual cooperation. "It is because good morals are so essential to successful cooperation that cooperation where possible is such an efficient aid in the development of better morality."

5. Proper Legislation.

A serious drawback was the want of proper legislation. Before the end of the period legislators were not very favorable toward cooperation. The laws of cooperation were often unfavorable toward cooperators. In the case of mining companies which brought suit to secure cooperation on the part of Railroad Companies in getting their product to market, almost invariably the state would settle in the favor of the railroad. The old established business worked against the new undertaking and legislation was one of its chief weapons of attack.

6. Central Organization.

\section{(2)}

A general organization to embrace all cooperative enterprises was very much needed. The enterprises which we have mentioned in our treatment of the subject of cooperation were, in the main, local. Very few were large enough to
(1) General Assembly Proceedings K. of I. 1888, Page 6; 1880, Page 171; 1882 Pages 320-21
Ford, "Cooperation in New England," Page 60
Coulter, "Cooperation Among Barmers," Page 22
Powderly, "Thirty Years of Labor," Pages 470 \& 398
Warner, "Three Phases of Cooperation in the West," Pages 101 \&c 55; North American Review 1893; "National Iabor Tribune"
(2) Waher "Three Phases of Cooperation in the West, "Page 101. 
attract more than $10 \mathrm{cal}$ interest. These veak, isolated units of cooperation did not bid high for success. What was called the American Cooperative Union was organized in Ohio in I886, with headquarters at Janesville, in the same state. Though it seemed to have a local origin, its aim was "to combine in one grand union all beneficiary, trade unions, education, religious, supply, distributive, productive, building and banking companies, societies, or associations of whatever name or nature, in order to bring about complete cooperation through the intervoven interests of all." From this we see commendable efforts, but the comprehensible aim was visionary. Efforts both in the East and West were being made at some sort of centralization for all cooperation, and the time did not seem far distant when the scheme would materialize.

(1)

7. Attitude of Officers.

Especially was it true of the Knights of Labor that the officers were unsympathetic toward cooperation. Powderly, the head of the order, was never very hearty in his commendation of cooperation. One reference is found where he made an appeal for a certain undertaking where the members had been (2) locked out. He was compelied to admit that most every effort

(1) General Assembly Proceedings K. of L. 1882, Pages 291, $285,313,320$ Proceedings 1888, Page 19 Commons, "History of Labor," Page 351 Powderly, "Thirty Years of Labor," Page 469

(2) Powderly, "Thirty Years of Labor," Pages 460-6I Proceedings 1885, Pages 18 \& 19. 
(1)

had been a failure, though these local attempts had been a. great boon in the direction of universal cooperation. None of the officers were enthusiastic toward local cooperation. The cormittee which was appointed to report on cooperation, expressed doubt that local attempts were to prove the best and that all must look toward universal cooperation through a thorough educational campaign. In the face of such neager support and sympathy from the officers, local cooperative attempts were destined to failure. In 1888, Powderly said "We have witnessed the expenditure of millions of dollars for the support of strikes, have seen the effects of boycotting; we have watched the course of our cooperative enterprises and as jet cannot say with any degree of satisfaction that much of good has resulted." He had said in the opening address of the session of 1886 , "A number of hasty attempts have been made to establish cooperative institutions, but they were not thought of until parties interested were locked out of employment or on strike. Every dollar invested under such circumstences is a dollar lost as far as cooperation is concerned." He makes an appeal for education, the crying need of cooperation. Many motions were made concerning cooperation in the meetings of the General Assembly. Some were in favor of entering upon an
(1) Ibid, Page 469
(2) Proceedings 1888, Page 8
(3) "Thirty Years of Labor," Page 469 
extensive campaign of cooperation, while others were in favor of doing away with any reference to cooperation. On the whole, the foregoing reasons for failure stand out as the most striking. Many other minor reasons could be assigned, no doubt. Lack of education, incompetent leadership, want of proper legislation, apathy on the part of the officers, lack of sufficient capital, jealousy on the part of those in the enterprises and out, desire for too speedy returns on investments, expectation of an immediate millenium, all held back the success of many sincere attempts born of rosy optimism. Many had the enthusiasm of children in their playhouse, and as much business in their operation. 
C H A P E V 
CHAPTER V

\section{BEINETTS}

Early efforts of labor to cooperate were schoolmasters in themselves. The greatest lessons are learned in the school of experience. We may safely say that the failures as well as the successes of wage-carners at cooperation were beneficia.. The failures may be classed as berefits when regarded in the light of the fact that we learn through experience, even though the experiment proves to be a failure. We learn how not to do a thing as well as how to accomplish it. Ihis fact applies to labor in its early years of organization. Ford, in his History of the Grange Movement, says that "Cooperation teaches the dependent, ignorant, shortsighted. Its very limitations are blotted out by the training which it gives."

(1) Vis limitations are plotted

More definitely, consider the education received through experience on the part of wage-earners in the period under consideration when related to the idea of cooperation.

In the first place, early laborers learned to a degree the (2) art of living together. Long had labor been, and so is it now: to some degree, unaware that it was possible for them to mutually aid each other; that one laborer could hot seclude himself from his fellow brothers and thrive as well as when he lived with them harmoniously and united. Jealousy and strife and suspicion have been eradicated from among laborers as they have Iearned each other as they have seen and appreciated each other's needs. The motto

(1) Ford, "Cooperation in New England" (Intro. by Peabody)

(2) Brooks, "Iabor's Challenge to the Social Order, "Pages 254 \& 260 
of the Knights of Labor was: "that is the most perfect government in which the injury of one is the concern of all." Being reminded constantly of this fact, it is safe to conclude that the laborer was more able to appreciate his brother than before any such ideal was broadcasted.

The second lesson learned from the school of experience was the knowledge of methods. Early leaders in any field of endeavor are vague and indefinite. How true this was of the efforts of wage-earners with little history to suggest methods. With raw, uneducated, untrained men with which to work, certainly there was plenty of difficulty encountered. Methods had to be tried, and if proved successful, accepted; if they proved not so good, to be rejected. In this way labor learned methods. May we suggest that this has always been the best way to secure methods and has been the source of our best methods in any field. Nethods, hatched from a so-called fertile mind, untried in the least, are often relegated to the trash heap - and rightly so. Slowness on the part of wage-earners to appreciate the value of trained leaders has alvays been a handicap. Though this has been improved, we do not see the shortsightedness entirely done away with. An illustration of this fact is the present organization among farmers in Kentucky. Complaint is heard regarding the high salaries paid to the heads of the association, and it is urged that men who will not require so much pay be put into office. But, on the whole, labor has come to recognize that if it is to succeed with its undertaking, it must have a fair appreciation of brain power.
(I) Preamble to $K_{\text {. of }}$. Constitution. 
Coulter, in his book "Cooperation Among Farmers," says that originally men did not need to cooperate, but that business competition has made it necessary. Labor has come to recognize this fact. The complicated, organized system of industry made it necessary for wage-earners to compete. In Coulter's book, we see again, "Civilization inplies sore measure of luxury and comfort. It can only be attained when the community is organized and has strength to retain some surplus, or wealth beyond what is required for the bare necessities of life. The organized commities are always wresting any surplus from the unorganized. The business mind of the country must be organized to counter the business mind of the town." The sentiment of this statement can well be applied to the wage-earners before the close of last century. They, too, were beginning to learn not only the value of cooperation but the sheer necessity of it.

Another thing that had begun to impress itself on labor was the fact that no genuine reform could come quickly. There must be time given if the evils of labor were to be corrected. Ignorance in general had caused the laborer to expect the advent of the millenium in a few weeks. The speech given by Geo. W. Russell in the introduction to Coulter's, "Cooperation Among Farmers," strikes the keynote of failure among farmers - the lack of education. This could also be applied to wage-earners. He says "Outside the cities there have always been the same neglect of culture, the same want of education, the lack of organized intellectual, political and economic power which set up a barrier between the country man and his access to the finer things of Iife." Experience had taught the laboring man to expect not too 
radical reforms and to improve his vision of the economic powers with which he must contend. He was beginning to do this nost needed thing and results were bound to come.

An article entitled "The Knights and the Trade" appearing in "Nation" 1887, said the Knights of Labor were slowly but surely reducing. The reason given was that they were undertaking things which were too radical. The "Nation" of 1888, Page 307, in an article headed "A banished Illusion", said that-in 1886 there were between $2,000,000$ and $3,000,000$ members in K. of I.; that they owned an executive mansion valued at $\$ 100,000$; and that the Grand Ilaster workman, Powder Iy, was paid a salary of $\$ 5000.00$ a year. The report of 1888 revealed the treasury to be empty, less than 200,000 members, and Powderly studying law as a future profession when his salary should cease. The General Assembly of 1886 had no report from the committees on cooperation, which revealed the attitude of the leaders toward immediate efforts at local cooperation. Powderly said at this meeting, "A number of hasty attempts have been made to establish cooperative institutions, but they were not thought of until parties interested were locked out of exployment or on strike. Every dollar invested under such circunstances is a dollar lost as far as testing the value of cooperation is concerned." He said in 1888, "We have watched the course of our cooperative enterprises, and, as yet, cannot say with any degree of satisfaction that much of good has (3)

resulted." Common says in his book that the Knights of Labor have

(1) General Assembly Proceedings K.of I. 1886 ("Thirty Years of Labor", Page 469)

(2) Powderly, "Thirty Years of Labor", Page 469 
contributed or bequeathed ideals rather than organization. These quotations are evidence of failure, as far as local attempts at organization are concerned, or as regards. organization in labor prior to the end of the period; but, nevertheless, we, again, are led to repeat that the efforts were not in vain. The beginning was made, defeats were encountered, men were taught, and they learned. Those efforts which were eventually to "make every man his own master, every man his own employer, and the system which will give the laborer a fair proportion of his toil" were destined to be realized. Universal cooperation was to be the cure for all the ills which had been attending labor. Local attempts were to fail, in the main, but the future held more than the irmediate advocates could see. Iven in our own age labor has not succeeded in realizing its fond hope, but the leaven is working, and the time is not far distant, let us hope, when "the injury of one" shall be "the concern of all."

(1) Motto of Knights of Labor PThirty Years of Labor", Page 105) 
Bemis, Edward $w_{.}$,

Brooks, John Graham, Brown, Mary Wilcon, Buck, S. J.,

Commons, J. R., Cooley's

Coulter, John Lee,

Eddy,

Fay, C.R.,

Fay, C.R.,

Ford, James,

Granland, Laurence,

Nolaughlin, Andrew Cunningham, "Steps in the Development of American Democracy."

Powderly, T.V.,

Powell, G. Harold,

Oliver \& Stratton,

Talman, William H.,
"History of Cooperation in the U.S." (Baltimore 1888, John Hopkins University Series)

Bemis and his associates have given an excellent account of efforts and failures of cooperative attempts in the United States.

"Labor's Challenge to the Social Order."

"The Development of Thrift."

"The Granger Hovement." (Harvard University Series, 1913). The best book I have read on the subject. He gives a detailed account.

"History of Labor in the United States."

"Social Organization."

"Cooperation among Farmers." (1911)

Coulter deals mainly with the necessity

"The New Competition."

"Copartner in Industry." (1913)

"Cooperation at Home and Abroad." (1908)

"Cooperation in New England." (New York 1913)

"The Cooperative Commonwealth." (Boston) of cooperation among farmers. 
Warner, Amos G.,

"Three Phases of Cooperation in the West."

"Cooperation Among Farmers and Consumers."

(A committee on special war activities National Catholic War Council, 1312 Ilass. Ave., I. W., Washington, D.C.)

"Marketing and Farm Credits."

(A collection of papers read at the third annual sessions of the National Conference on Marketing and Farm Credits in Chicago, 1915)

"Cooperative Purchesing and Marketing Organizations Anong Farmers in U.S." (Washington Government Printing Office) O.B. Jansen and W.H. Kerr. Assist. in Cooperative Agriculture and Investigator in Market Business Practice.

"General Assembly Proceedings of the Knights of Labor."

"Class Discussions, Social Seminar, University of Louisville." 1925-6 